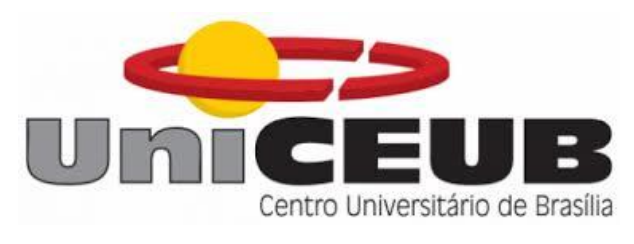

CENTRO UNIVERSITÁRIO DE BRASÍLIA - UNICEUB

FACULDADE DE CIÊNCIAS JURÍDICAS E CIÊNCIAS SOCIAIS - FAJS PROGRAMA DE INICIAÇÃO CIENTÍFICA

MARCO VINÍCIUS GOMES CRUZ DE QUEVEDO

RELAÇÕES SINO-BRASILEIRAS: DA HORIZONTALIDADE NO SÉÇULO XX PARA A VERTICALIDADE NO SÉCULO XXI

Brasília, DF

2017 


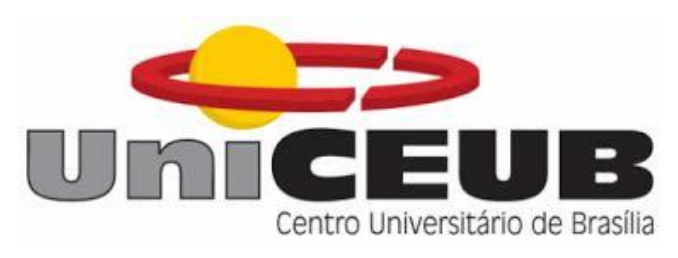

MARCO VINÍCIUS GOMES CRUZ DE QUEVEDO

RELACCÕES SINO-BRASILEIRAS: DA HORIZONTALIDADE NO SÉÇULO XX PARA A VERTICALIDADE NO SÉCULO XXI

Relatório final de pesquisa de Iniciação Científica apresentado à Acessoria de Pós-Graduação e Pesquisa pela Faculdade de Ciências Jurídicas e Sociais - FAJS

Orientador: Prof. João Paulo Santos Araujo

Brasília, DF

2017 
"Latin America represents one of the most dynamic regions of the planet in terms of economic development. In the political sphere,

the region, particularly Brazil, occupies an important strategic position in the world. Brazil is the largest developing nation in Latin America, and China is the largest developing nation in the world. There are many similarities between the two countries: they both intend to reach economic development and improve the living conditions of their population. Thus, cooperation carries a very significant meaning for both countries, as there is no fundamental conflict of interests. In fact, the two countries are complementary. Therefore, I see a very promising horizon for relations between our two countries, especially in the economic field."

\section{Presidente do Comitê Nacional da Conferência Consultiva Política do Povo Chinês, Li Ruihuan.}




\title{
RELACCÕES SINO-BRASILEIRAS: DA HORIZONTALIDADE NO SÉCULO XX PARA A VERTICALIDADE NO SÉCULO XXI
}

\author{
Marco Vinícius Gomes Cruz de Quevedo - UniCEUB, PIC Institucional \\ vinicius-quevedo@hotmail.com
}

João Paulo Santos Araújo - UniCEUB, professor orientador

joao.araujo@uniceub.br

O presente trabalho faz uma análise qualitativa - a partir de pesquisa bibliográfica a artigos correlatos e em fontes com dados primários como documentos oficiais e relatórios publicados por entidades de governo - das relações de cooperação entre Brasil e China no período de 1964-2015 com objetivo de esclarecer em que medida há uma relação horizontal ou vertical entre os agentes nos últimos anos. Para isso, buscou-se descrever e analisar as relações históricas, comerciais e políticas entre eles pelo prisma da Teoria do Sistema Mundo, associando-a às prerrogativas conceituais da cooperação internacional nas Relações Internacionais. A relevância se dá pelas transformações ocorridas no sistema internacional quando da alçada da China ao status de potência global e da influência do país asiático no ambiente latino-americano. O escrutínio dividiu a relação bilateral entre os períodos de 1964-2000 e de 2001-2015, já que se considera que entre o primeiro período analisado e o segundo há evidente transformação no comportamento dos agentes, principalmente em suas relações comerciais. A pesquisa constata que no início das relações sino-brasileiras houve maior engajamento em iniciativas de cooperação para o desenvolvimento por meio de ações de cooperação técnica com características consideradas de perspectiva Sul-Sul. Entretanto, nos últimos anos, nota-se uma maior disparidade nessa relação como consequência do aumento do intercâmbio comercial, e, em decorrência disso, uma maior dependência brasileira às exportações para a China, impactando diretamente nas relações políticas, além de um impacto nas práticas de cooperação entre eles. Ao fim, conclui-se que a interação entre Brasil-China passa a ter novas características no século XXI sendo visível uma verticalização desta relação.

Palavras-Chave: Brasil-China. Cooperação Horizontal. Cooperação Vertical.

Sistema Mundo. 


\section{Sumário}

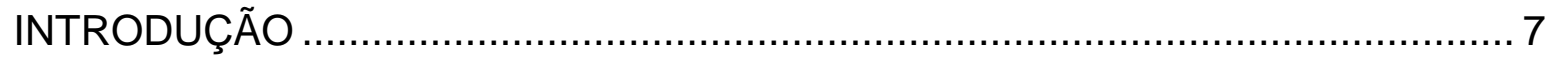

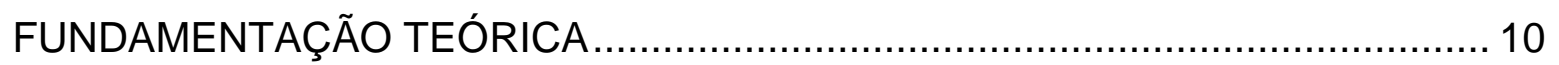

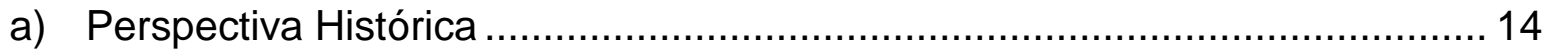

b) Origens do sistema mundo: Marx e Lenin .............................................. 17

c) Sistema Mundo Moderno e diferentes perspectivas .................................... 21

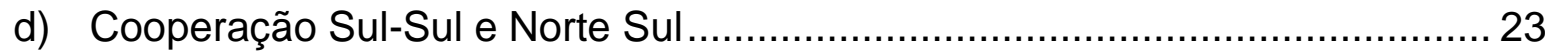

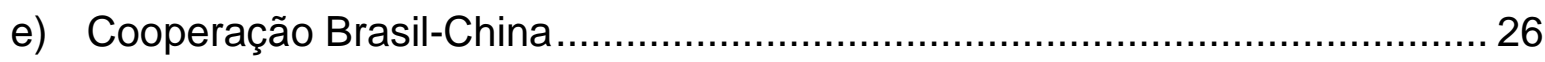

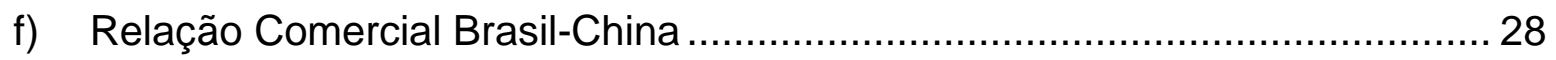

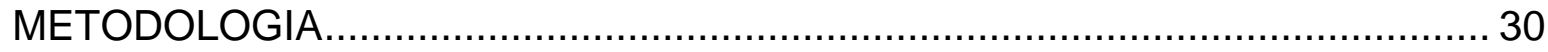

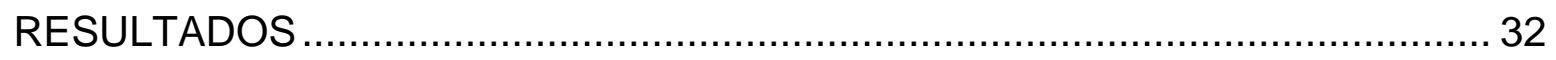

I. Distanciamentos e aproximações: A Cooperação Bilateral Brasil-China (1964$2000)$

II. A nova pauta: relações comerciais Brasil-China (2001-2015) ..................... 41

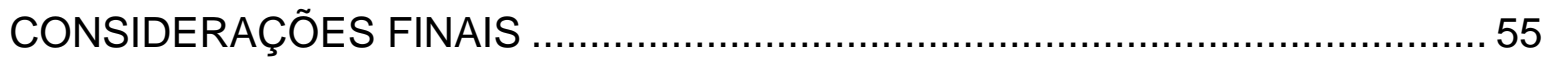

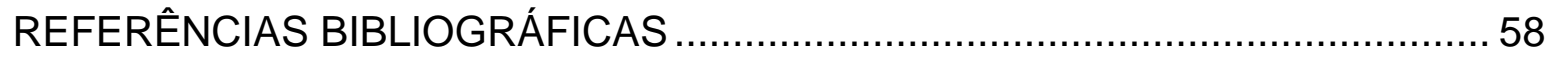




\section{TABELAS}

TABELA I: QUADRO DE EXPORTAÇÃO BRASILEIRA PARA A CHINA ............ 33 TABELA II: IMPORTAÇÕES BRASILEIRAS DA CHINA EM (1986 E1991)........... 34 TABELA III: BRASIL PRINCIPAIS PRODUTOS IMPORTADOS DA CHINA (1993 a 1995) 36

TABELA IV: PAUTA DE EXPORTAÇÃO DO BRASIL PARA A CHINA (1993 a 1995) 36

TABELA V: PAUTA DE EXPORTAÇÃO DO BRASIL PARA A CHINA (1997 A 1999) 38

TABELA VI: BRASIL PRINICIPAIS PRODUTOS IMPORTADOS DA CHINA (1997 a 1999) 39

TABELA VII: PRINCIPAIS PARCEIROS COMERCIAIS DO BRASIL 44 TABELA VIII: PAUTA DE EXPORTAÇÃO DO BRASIL PARA A CHINA (2001) ... 45 TABELA XIX: BRASIL PRINCIPAIS PRODUTOS IMPORTADOS DA CHINA (2013-2014)

TABELA X: B PAUTA DE EXPORTAÇÃO DO BRASIL PARA A CHINA (20132014) 49

TABELA XI: PRINCIPAIS PARCEIROS COMERCIAIS DO BRASIL (2014 E 2015)....... 48

TABELA XII: PRINCIPAIS PARCEIROS COMERCIAIS DA CHINA (2011).... 49 TABELA XIII: EVOLUÇÃO DO COMÉRCIO BRASIL-CHINA (20062016). .51

TABELA XIV: PAUTA DE EXPORTAÇÃO DO BRASIL PARA A CHINA (20152016) .51

TABELA XV: BRASIL PRINCIPAIS PRODUTOS IMPORTADOS DA CHINA (2015-2016)...... .52 


\section{INTRODUÇÃO}

As relações comerciais e políticas entre o Brasil e a China se desenvolvem desde a década de 1960. Porém, devido a instauração do governo militar no Brasil, só houve maior aprofundamento a partir da década de 1970. Os países demonstravam um alinhamento favorável em vários âmbitos, tendo em vista o foco na criação de instrumentos para o desenvolvimento mútuo de Estados semiperiféricos e as similaridades na essência de seus princípios de política externa diante do arranjo da sociedade internacional.

Os dois países, num primeiro momento, se engajaram em ações de cooperação técnica e numa agenda comum para os países do Sul, com a retórica de se distaciarem da ajuda externa prestada pelos países desenvolvidos. Contudo, a partir da década de 1990, o comércio passou a prevalecer nessa relação e tornou-se a principal pauta das relações bilaterais, conseguindo influenciar em todas as outras perspectivas de cooperação. Do lado brasileiro, percebe-se uma prevalência da exportação de matérias primas para a China, enquanto que a China passou a exportar, principalmente, produtos de alto valor agregado para o Brasil.

No contexto contemporâneo a China se consagra como um relevante ator econômico para o sistema internacional. Por um lado, o crescimento chinês é acima da média dos outros Estados do mundo e se aproxima com os países em linha de desenvolvimento. Foi assim que o país asiático transformou-se, em 2009, no principal parceiro comercial do Brasil. Por outro lado, o Brasil suscita interesses na China por se caracterizar como uma importante fonte supridora de matériasprimas,no século XXI, principalmente produtos alimentícios e insumos básicos. Nesse âmbito, à medida que a China se dinamiza e se especializa em produtos manufaturados, característica própria de países desenvolvidos, é mantido ou ampliado o interesse na importação de produtos básicos do Brasil.

Com base nesses elementos, buscou-se um instrumento conceitualteórico para analisar as nuances dessa relação. A perspectiva teórica escolhida Teoria do Sistema Mundo - coloca que os dois países possuem características de 
serem Semiperiferias.O Sistema Mundo teve sua origem na Europa e em algumas partes da América, logo se expandiu em todo o globo, sendo uma das primeiras teorias que conseguiu se auto delimitar na própria construção de uma economia mundo capitalista (WALLERSTEIN, 2004). É delimitado como um sistema que expõe atores interligados e que resultam de um único processo histórico, apresentando-se como uma espécie de sistema social unificado, o qual pode ser definido como uma unidade com uma divisão do trabalho singular (labor and hence) e com múltiplas culturas, também interpretado como "world economy". $\mathrm{Na}$ estrutura da economia mundo são necessários múltiplos Estados e a interação entre mercados e investimentos que formam o sistema, o que será fortemente caracterizada pelo capitalismo. Brasil e China, a partir das camadas do sistema mundial, estão entre o Centro e a Periferia, contudo, o sistema mundo moderno trás uma nova perspectiva dos países semiperiféricos na qual alguns conseguem desenvolver capacidades o suficiente para tornar Estados Centrais, como no caso da China pelo âmbito econômico. Enquanto isso, o Brasil continua explorando os países perféricos e ao mesmo tempo sendo explorado pelos países centrais.

Contudo, há uma dicotomia na interpretação dos fatos e principalmente na posição da relação bilateral dos dois países. Percebe-se que a atual relação é benéfica para o Brasil, entretanto, em uma perspectiva em longo prazo, expõem maior relevância para a China (VADELL, 2013). A partir dessa visão, é notável que a interação entre esses agentes que estariam em grau de desenvolvimento relativo próximo, nos âmbitos tecnológico e social aproximar-se-ia da perspectiva Sul-Sul de cooperação no século XX. Isso fica claro em na cooperação criada para o desenvolvimento de países do eixo Sul-Sul da década de 1980, em que defendem a mútua colaboração das partes para fins comuns e ganhos mútuos. Entretanto, percebe-se na prática que essa interação beira a transferência de recursos e tecnologia de forma verticalizada, a partir do aumento da relação comercial no século XXI, bem aproxima daquela relação previamente estabelecida entre ofertantes e recebedores de cooperação nas décadas que sucederam a segunda guerra mundial, o que possibilita maiores ganhos à China. Dessa forma, busca-se analisar - aproveitando a flexibilidade que a Toeria do Sistema Mundo 
oferece ao ser aplicada em diversos períodos distintos acompanhando as transformações do sistema -, se há nova configuração da relação Brasil-China no século XXI e refletindo se uma relação Sul-Sul é construída ou se, na verdade, há a materialização de uma relação Norte-Sul. 


\section{FUNDAMENTAÇÃO TEÓRICA}

A análise proposta requer um aparato conceitual-analítico robusto para tratar da perspectiva bilateral Brasil-China. Por tal motivo utilizou-se como embasamento teórico a Teoria do Sistema Mundo, tendo como foco sua aplicação diante das premissas da cooperação Sul-Sul e Norte-Sul.

Diante disso, Viotti e Kauppi (2012), colocam que o capitalismo não é a mera existência de produção para venda em mercados com a intenção de obter lucro, tampouco a existência de pessoas trabalhando por seus salários. Tais definições não são suficientes para descrever o capitalismo. O capitalismo se sustenta em uma estrutura social quando o sistema estatal dá prioridade a acumulação infinita de capital. A prioridade à acumulação sem fim é imposta através de mecanismos estruturais que penalizam de alguma forma aqueles que possuem atitudes diferentes das então internalizadas pelo capitalismo, enquanto que aqueles que possuem atitudes apropriadas ao sistema são recompensados de alguma forma, fazendo com que alguns deles se tornem ricos. Utilizando desta definição, apenas o sistema mundo tem sido um sistema capitalista, principalmente pela sua caracterização de um sistema desigual (VIOTTI, KAUPPI, 2012).

Para Wallerstein (2004), o sistema capitalista é a acumulação incontrolável do capital. Assim, a economia-mundo e o capitalismo andam juntos, já que não havia uma estrutura política solidificada ou outra cultura hegemônica. Dessa forma, o que os mantém juntos é a eficácia da divisão do trabalho (WALLERSTEIN, 2004). Ela é a função de constante expansão da riqueza que o sistema capitalista provoca.

O capitalismo requer uma atenção especial pelos empresários e os detentores do poder político. Precisa de grandes mercados e principalmente da pluralidade de Estados. É a partir dos Estados que a zona de interesses ou vantagens absolutas se intensifica com a existência de múltiplos Estados que irão assegurar a divisão do trabalho. 
A constituição dos Estados é um dos principais conceitos da teoria do sistema mundo, afinal de contas as relações comerciais e políticas de todo o sistema, são constituídas, também, pelos Estados. A formação e o desenvolvimento do maior e mais duradouro sistema é um dos pontos principais para toda a estrutura do sistema mundo modernos (HOPKINS, 1982).

Portanto, o Estado está inerentemente ligado ao mercado, ambos são produtos de uma época particular e estão firmemente dentro de uma raiz social mais ampla (GILPIN, 2002). Este mercado é considerado uma estrutura na qual indivíduos ou empresas vendem seus produtos. Não são totalmente livres, logo, as fontes de produção não são totalmente abertas. Pela lógica capitalista, na perspectiva de acumulação de capital, um monopólio é preferível já que a margem de preços e de "labor" serão perpetuadas e designadas por apenas um agente. Entretanto, perfeitos monopólios são difíceis de serem criados, mas os "quase monopólios" não são (VIOTTI, KAUPPI, 2012).

Por conseguinte, a divisão do trabalho dentro da economia mundo capitalista, a partir dos mercados, possui a tarefa de entender a economia política internacional em um núcleo dominante e uma periferia dependente que interagem e funcionam como um todo integrado (GILPIN, 2002). Os "quase monopólios" são largamente alocados dentro de uma proporção sócio-global, já que dependem dos Estados nacionais para existir.

Como exposto por Gilpin (2002), embora o sistema pluralista de Estados seja o requisito primordial para a criação de uma economia mundial, a interação entre o comércio mundial e os investimentos é o mecanismo principal para a estrutura do sistema. Wallerstein (2004) coloca que a organização da produção global é caracterizada por uma crescente especialização regional, possuindo diferentes métodos de controle do trabalho. Ela seria uma estrutura internacional desigual de Estados que mantém a divisão internacional do trabalho e é responsável pelo acúmulo de riquezas dos Estados capitalistas mais avançados e 
pelo ciclo de atraso nos subdesenvolvidos e nos demais. Ou seja, essa estrutura é definida por uma divisão desigual internacional do trabalho.

Como exposto por Wallerstein (2004), existem três camadas de Estado que são os principais componentes dessa divisão internacional do trabalho. São ordenados hierarquicamente e diferenciados pela posição que conseguirem na estrutura da economia mundial, sendo o centro, a semiperiferia e a periferia. Os estados do centro tendem a se especializar na indústria e tecnologia (muitos formam os maiores semi monopólios), a periferia é o principal polo de matérias primas e a semiperiferia está entre essas duas camadas.

Uma das características dos estados centrais é a sua imposição hegemônica perante aos outros na estrutura da economia mundial. Normalmente, essas zonas se convertem em centrais, por dominar o processo de exploração e principalmente pela concentração de mais-valia. Os processos de centro consistem na modernização tecnológica, salários relativamente altos e tipos de produção diversificados, dessa forma comandando todo o sistema econômico mundial (PRECIADO, 2008). Martins (2015) expõe o aspecto político desses Estados sendo fortes, tendo a alta capacidade de ampliar seus domínios para além de suas fronteiras, possuem alto apreço para o aspecto cultural o qual possuem forte identidade nacional e conseguem ampliar sua identidade como referência para além de suas barreiras geográficas. Estes Estados são altamente especializados nos meios industriais o que os tornam capazes de monopolizar as fontes mais modernas de produção tecnológica. Assim, possuem grandes relações com as zonas periféricas, com o intuito de explorar suas principais reservas naturais (WALLERSTEIN, 2004).

Dessa forma, o centro também influencia no processo das zonas periféricas onde são definidos pela condição de exploração pelo centro e subordinados aos seus processos centrais e concentrados de recursos naturais. $A$ periferia é constituída de tecnologia rudimentar o que resulta numa produção simples, sendo ela essencial para o centro (PRECISADO, 2008). Os Estados da periferia não possuem nenhuma identidade nacional e sim fragmentações 
identitárias. Prevalece a religião ou a ética imposta pelo centro, não conseguindo exercer nenhuma influência externa (MARTINS, 2015). Wallerstein (1996) define a periferia de uma economia mundo como aquele setor geográfico onde a produção é de bens de baixa categoria, produtora de bens de mão de obra barata, porém é parte integrante da divisão internacional do trabalho. São estados mais fracos perante outros dentro da economia mundo, não estabilizados e dependentes do centro, por isto suas relações com o centro são de alto valor.

Para o autor Zarycki (2007), a perspectiva da relação centro e periferia da escola do relativo desenvolvimento, expõe o viés da dependência de países Latinos Americanos no desenvolvimento dos países centrais. Neste entendimento a periferia torna-se dependente por consequentemente influenciar na industrialização do centro, através da comercialização de produtos naturais, sendo de grande maioria na exportação de commodities ${ }^{1}$.

Logo, a semiperiferia estaria entre o centro e a periferia, sendo um espaço que combina ambos os processos. Sua principal característica é no relativo processo de variadas produções o que o coloca em uma situação difícil. Estados semiperiféricos estão sob pressão dos Estados do centro e colocam pressão nos periféricos. O principal objetivo é manterem-se longe de adentrar na periferia e fazer o que podem para tornarem-se centro. Estes estados semiperiféricos estabelecem agressivas barreiras protecionistas com o intuito de proteger seus processos de produção da grande concorrência no exterior (VIOTTI, KAUPPI, 2012).

Diante disso, a economia mundo seria aquilo que aceita um centro, um país dominante. Um modelo de economia podendo existir vários centros numa mesma economia-mundo. Esta seria a ideia em termos de acumulação de capital para o sistema como um todo, tendo o centro como criar um poder hegemônico, sendo forte o suficiente para definir as regras do sistema internacional e para supervisionar se todos os outros Estados, da periferia e da semiperiferia, estão as seguindo (WALLERSTEIN, 2004).

1 Produtos de matéria prima que são comercializados em larga escala, como: Soja, carne, minerais, entre outros. 
Neste sentido, segundo Hopkins (2012), o subdesenvolvimento não seria uma anomalia e sim o sentido mais correto do que o sistema capitalista e de acumulação de riquezas impõe no sistema-mundo, tornando-se uma parte essencial para o seu funcionamento.

Em vista disso, o sistema mundo capitalista (ou moderno) cria uma estrutura mundial que é interligada em uma só. O novo sistema possui uma estrutura que consiste neste sistema social vigente, que consiste de: expansão da economia; expansão de múltiplos estados; e a relação do capital labor. Neste sistema social, o melhor conceito a designá-lo é o de "desenvolvimento" (HOPKINS, 1982). A perspectiva histórica da teoria do sistema mundo, será tratada no próximo ponto e dará maior embasamento para expor o sentido do conceito e como, ainda, pode ser utilizada como embasamento das relações Brasil-China.

\section{a) Perspectiva Histórica}

O pensamento da teoria do sistema mundo, como estrutura, começou a surgir no século XVI, com o advento do capitalismo e do novo mercado europeu que começava a abranger o mundo e dar início à economia mundo. As novas dimensões eram dimensões de um império e conseguia abranger um sistema mundial que possibilitaria ser maior do que qualquer unidade política juridicamente definida. Neste novo sistema, existiam duas instituições chaves: a divisão mundial do trabalho e a existência de aparelhos burocráticos do Estado (ARRUDA, 1983).

Em um primeiro momento é importante frisar a divisão do trabalho produtivo, que consiste na transformação das formas feudais em formas capitalistas de produção agrícola, o que manifesta o surgimento do "proprietário" e em que a força do trabalho era determinada pelo poder econômico. Iniciava o controle do trabalho agrícola para o mercado. A partir desta nova premissa que se constituía no mundo, a grande abertura e expansão econômica foram as grandes

contribuintes para que estruturas burocráticas do Estado se firmassem. A Monarquia Absoluta se viu obrigada a levar em consideração as novas indústrias 
comerciais agrícolas, resultando em um grande apoio fiscal à monarquia como contribuinte e um novo sócio comercial (ARRUDA, 1983).

Nos séculos XVII e XVIII, entre os anos de 1600-1750, há a consolidação da economia mundo com o advento do mercantilismo e a solidificação da economia europeia. O mercantilismo se torna a nova hegemonia do sistemamundo (CAMERON, 1981). Assim, em primeiro plano as exportações e importações de matérias primas, principalmente no caso da Companhia Holandesa das Índias Orientais, começam a definir a estrutura. Num segundo momento, as disputas comerciais entre a Inglaterra e a França, como países do centro, logo definem o termo semiperiferia, o que é colocado em campo de visão sendo os países expoentes: Espanha, Suécia, Prússia (JONES, 1981)

Em seguida, nos anos de 1730-1840, começa a se concretizar o sistema mundo moderno ou sistema mundo capitalista. Este período é destacado pela contribuição da Revolução Industrial na Inglaterra, na qual remonta toda a estrutura total capitalista mundial em que máquinas começam a tomar espaço. Mercados, empresas, sistema de Estados nacionais começam a se polarizar substituindo os sistemas imperiais pré-modernos, oportunizando para que grandes mercados capitalistas escapassem do controle político e liberassem para desenvolver e transformar a economia mundial de acordo com sua lógica interna (GILPIN, 2002). Portanto, toda a divisão mundial do trabalho, que já estava a todo vapor sendo instaurada desde então, é reestruturada na economia mundial. De forma retórica, é importante notar a tardia Revolução Francesa, em comparação com a economia capitalista que se firmava o que denota a competição ideológica e comercial das duas maiores hegemonias da época (França e Inglaterra), sendo uma das características do sistema mundo de países centrais. Wallerstein (2004) descreve a intromissão de áreas não europeias, como na exportação de recursos naturais, na economia mundial que se firmava, sendo perceptível a definição de países periféricos. Territórios como Índia, África Ocidental e Rússia de alguma forma são afetadas dentro deste sistema, ocasionando a participação destes países, principalmente no campo agrícola capitalista (POLLARD, 1989). 
No período de 1815-1914, o sistema mundo passa a ser transformado em um novo hemisfério empreendedor, advindo de consequências do rápido avanço tecnológico industrial. Neste período é visível a mudança da divisão internacional do trabalho e a nova configuração da economia mundo no teor capitalista. Segundo Wallerstein (2004), o liberalismo tornava-se a nova geocultura do sistema mundo, ondas conservadoras e radicais exploravam os princípios de inclusão e igualdade para manter vantagens sobre as massas. O centrismo liberal com uma grande vantagem do capitalismo industrial, constituía nova face para a divisão internacional do trabalho. Assim, o século dezenove foi dominado pelos estados centrais que aderiram ao centro liberal imperial, os quais impulsionaram uma reforma populacional em que simultaneamente incentivasse o crescimento econômico e o controle das classes internas (WALLERSTEIN, 2011).

A partir de 1917, há a consolidação do novo sistema vigente a economiamundo capitalista até a atualidade, o que inclui as tensões econômicas e revolucionárias que esta nova consolidação provocou (MARTINS, 2015).

Desse modo, o sistema mundo moderno, que se perpetua até os dias atuais, tem como característica uma complexa relação na economia mundo entre empresas, Estados e instituições familiares que ligam todos os membros de diferentes classes e grupos, onde criam dois temas ideológicos que dominam toda estrutura como o universalismo, o racismo e o sexismo. $O$ universalismo dá prioridade para as regras gerais serem aplicadas igualmente para todas as pessoas e rejeitar suas particularidades e preferências fazendo com que a economia mundo melhore a capacidade de acumulação de capital.

O racismo e o sexismo, são termos que se tornaram significativos na fase contemporânea da economia mundo. Significam a discriminação dada a grupos, pessoas ou identidades que não participam do topo (centro) do "ranking" criado pelo capitalismo na estrutura da economia mundial, ou seja, no sistema mundo moderno. Tais termos possuem performances iguais e de importantes alocações de trabalho, poder e privilégio dentro do sistema mundo. Como exposto por Wallerstein (2004): 
We are all quite familiar with the worldwide rankings within the modern world-system: men over women, Whites over Blacks (or non-Whites), adults over children (or the aged), educated over less educated, heterosexuals over gays and lesbians, the bourgeois and professionals over workers, urbanites over rural dwellers. Ethnic rankings are more local, but in every country, there is a dominant ethnicity and then the others. Religious rankings vary across the world, but in any particular zone everyone is aware of what they are. Nationalism often takes the form of constructing links between one side of each of the antinomies into fused categories, so that, for example, one might create the norm that adult White heterosexual males of particular ethnicities and religions are the only ones who would be considered "true" nationals. ( WALLERSTEIN, 2004, p 40)

Dessa forma, o sistema mundo instaurado nos séculos XVII e XVIII, não foi totalmente alterado em sua essência e sim se reproduziu na medida que os ricos se tornaram mais ricos e os pobres mais pobres (GILPIN, 2004). O sistema mundo foi se criando dentro de sua própria estrutura na economia mundial. $O$ mundo foi se transformando em Estados que se originaram dentro da economia mundo onde se dividem a partir da criação da estrutura do trabalho advinda do capitalismo, dentro de suas próprias barreiras comerciais e atualmente dentro de um sistema mundo em que a existência de normas progressivas universais e de práticas discriminatórias são essenciais para a acumulação cada vez mais infinita de capital.

\section{b) Origens do sistema mundo: Marx e Lenin}

Os autores Marx e Lenin, a partir de seus pensamentos marxistas, proporcionam maior influência à Teoria do sistema mundo. Exibem a estrutura da economia mundo com premissas da acumulação de capital, monopólio e a divisão 
do trabalho, o que demonstra margem para expor o desenvolvimento do sistema mundo moderno na escalada capitalista mundial.

O foco da acumulação de capital é na extensão do crescimento e a complexidade de forças produtivas na mecanização crescente, devido às pressões sofridas pelo sistema capitalista. A perspectiva adotada é a dos proprietários de meios de produção e os empregadores de trabalho assalariado para reduzir os custos globais de produção (HOPKINS, 1982):

Central to the formulation are two ideas. One concerns the productions (here including distribution) by the work force of commodities "of more value than that of the elements entering into" their production [..] The other concerns the "realization" and appropriation by capitalists of this surplus value in money form through the sale of produced commodities and the use of portions of this realized surplus to pay for additions to capital, specially fixed capital. (HOPKINS, 1982, p14).

A acumulação de capital é o resultado de vários conceitos, como: o crescimento da concentração do capital; a competitividade de eliminação das pequenas forças de produção; a proporção de crescimento da sociedade avaliada no empoderamento de capital, entre outras (HOPKINS, 1982).

A teoria do sistema mundo moderno explica a necessidade da criação de um sistema desigual a partir da concentração de capital em determinados Estados ou até mesmo instituições privadas criadoras da força de trabalho. Neste ponto, os níveis salariais são importantes para a acumulação de riqueza, como explicado por Hopkins (1982):

In the form in which the theory is presented, this replenishment occurs through the capitalists paying workers money (wages) for their commodity (labor power) and the latter paying merchants the money for their commodities, 
namely, means of subsistence (or consumer goods). (HOPKINS, 1982, p 18 )

Marx argumenta que o capitalismo, o qual envolve mercados, trabalho como mercadoria e meios de produção normalmente mantidos em meios privados, produzem efeitos particulares na política, no social e na cultura. Tal fato influencia toda a estrutura econômica. Para o autor, o capitalismo exibe certas leis de qualidades em termos de desenvolvimento e expansão econômica, que devem ser seguidas.

He viewed capitalism as part of a world historical process unfolding dialectically, an economic system riddled with clashing contradictions or internal tensions that could be resolved only by a revolutionary transformation into a socialist mode of production [...]"Men make their own history, but they do not make it just as they please; they do not make it under circumstances chosen by themselves, but under circumstances directly found, given, and transmitted from the past. The tradition of all dead generations weighs heavily like a nightmare on the brain of the living." (VIOTTI e KAUPPI, apud MARX, 2012, 1972)

Com isso, a estrutura da economia mundo cria uma nova estrutura desigual, perante a divisão internacional do trabalho.

The fact that particular states change their position in the world economy, from semiperiphery to core say, or vice versa, does not in itself change the nature of the system. These shifts will be registered for individual states as 'development' or 'regression'. The key factor to note is that within a capitalist world-economy, all states cannot 'develop' simultaneously by definition, since the system functions by virtue of having unequal core and peripheral regions. (WALLERSTEIN, 1979, p. 61) 
Para efeito de controle de tal estrutura desigual, o sistema capitalista internacional cria formas de defesa dentro do sistema mundial de comércio, como barreiras comerciais. $\mathrm{O}$ intuito é de diminuir tais desigualdades, porém, na verdade seriam apenas métodos para incentivar desigualdades. Como exposto por Gilpin (2000), tais barreiras são criadas pelo próprio mercado para dar forças e sentido aos âmbitos comerciais mundiais.

Para Lênin, o capitalismo tem avançado dentro do sistema mundo oprimindo os estados colônias, sendo os países periféricos, na forma de um estrangulamento financeiro em cima da maioria populacional influenciada por países avançados, ou seja, o centro. O Imperialismo pode ser explicado na simples mudança natural das relações de produção capitalista. O autor coloca que a melhor definição para imperialismo seria monopólio, onde viria da concentração monetária como os bancos, o surgimento das associações monopolísticas industriais e das aquisições territoriais monopolísticas dos Estados avançados. (LORIMER, 1999)

Lenin, nota cinco características básicas do imperialismo no estágio capitalista,

(1) the concentration of production and capital has developed to such a high stage that it has created monopolies which play a decisive role in economic life; (2) the merging of bank capital with industrial capital, and the creation on the basis of this "finance capital", of a financial oligarchy; (3) the export of capital as distinguished from the export of commodities acquires exceptional importance; (4) the formation of international monopolist capitalist associations which share the world among themselves; and (5) the territorial division of the whole world among the biggest capitalist powers is completed. (LORIMER, 1999, p 10)

Nesse sentido, Lênin expõe sua lógica imperial que possui como resultado direto o monopólio do capital. Para 0 autor o capitalismo tem 
desenvolvido os oligopólios e os monopólios no qual conseguem controlar todos os setores chaves da economia, aniquilando as pequenas empresas ou as comprando. O que torna os Estados do centro mais fortes, tendo como impacto as empresas imperialistas mundiais. (VIOTTI, KAUPPI, 2012)

Assim, os autores contribuem para a explicação da estrutura em seu total, mostrando a desenvoltura do sistema mais forte para uns e fraco para outros, o que tem sido definido pela conjuntura do sistema mundo capitalista atual.

\section{c) Sistema Mundo Moderno e diferentes perspectivas}

A estrutura do sistema mundo sofre transformações constantes, devido à reprodução da estrutura da economia mundial. Desde uma perspectiva histórica, como proposto por Hopkins (1982), o sistema mundo pode ser testado em vários períodos distintos de maneira hipotética, ocasionando várias questões sobre as operações do sistema mundo moderno na estrutura processual econômica vigente da atualidade (1982). Hipóteses concisas, com fatores empíricos, podem ser retiradas da teoria, o que nos revela uma relação bastante abrangente do que 0 sistema mundo pode significar para a conjuntura de todo o sistema mundial atual.

$\mathrm{Na}$ conjuntura capitalista global atual, a economia mundial é um constante emaranhado de políticas estatais e de âmbitos privados (constituindo a sociedade civil e empresas de capital privado). Como colocado por Gilpin (2000), a crise americana na década de 90 atingiu vários países no âmbito econômico, como o Japão e a Europa e, de certa forma, vários outros Estados. Outro fator seria a força do capitalismo que mais se adere à conjuntura total, advinda do desenvolvimento cotidiano de tecnologia, principalmente a tecnologia vinda dos países do centro. Países esses que para Gilpin (2000) são essenciais para que o capitalismo tome cada vez mais força na conjuntura econômica mundial. Dessa forma, o sistema mundo é definido como um todo integrado, entre todos os Estados e empresas, não sendo totalmente influenciado e regrado por Estados de centro, mesmo estes sendo possuidores da hegemonia da economia mundial.

Numa outra perspectiva, Preciado (2008) traz como matriz a fonte interestatal de estrutura do sistema mundo como explicação para a atual 
conjuntura mundial. O principal processo tripartite da economia mundo sendo centro, periferia e semiperiferia, é o divisor de águas do capitalismo. "Implicam uma representação espacial do mundo ligada às mudanças de ritmo dos ciclos de auge e crises dos que estão submetidos à economia capitalista" (PRECIADO, 2008, p.2).

Outro fator são os países que representam as semiperiferias (como Brasil, China, Rússia) os quais representam um papel importante nos seus processos de centro e periferia. Essas zonas, na verdade, se convertem em centrais porque dominam todos os processos de mais-valia e principalmente são consideradas como subordinadas de zonas do centro, quando na verdade colocam todo o seu principal poder na concentração de recursos, sendo muitas das vezes recursos naturais (PRECIADO, 2008 apud SCHWARTZMAN, 2006)

Neste sentido a semiperiferia, seria a zona que mais combina entre 0 centro e a periferia, principalmente pela produção industrial mais dinamizada.

A semiperiferia é o espaço que combina, de uma forma particular, ambos os processos. Esse conceito se aplica diretamente às zonas, regiões ou Estados que supõem a exploração da periferia e sofrem a exploração do centro. (PRECIADO, 2008, p 03)

Deste modo, a capacidade desses países em fazer parte do centro é outro fator que vem à tona na atual conjuntura do sistema mundo moderno. A convergência global atual é vista em diversos campos, na qual incluem âmbitos sociais, econômicos e políticos em uma maior escala e muito devido à globalização. Segundo Schwartzman (2006), "[..] the world-system perspective offers better theoretical leverage for synthesizing the myriad strands of research and the extremely diverse research findings. It also provides a more persuasive explanation for the observed global convergence." (2006, p. 01).

Dessa forma, a estrutura do sistema mundo é constituída por diversos fatores que expõem a complexidade de se criar hipóteses, devido à constante mudança do sistema global. Entretanto, a teoria é de grande importância para a 
interpretação do sistema na qual constitui todo o arcabouço unitário do sistema internacional. O que demonstra grande importância no estudo para a demonstração das características de Centro e Periferia entre o Brasil e a China.

\section{d) Cooperação Sul-Sul e Norte Sul}

Após o término da segunda guerra mundial, o sistema internacional reconfigurou-se. Dois grandes pólos de poder surgiram diante do sistema e a grande maioria dos Estados Aliados saiu da guerra destruída. Com isso, diante da marginalização desses estados falidos e com a nova estrutura do sistema internacional que tomava impulso, entendeu-se que a criação de um órgão assistencial era necessária e imediata.

Com a separação do mundo em dois grandes pólos de poder pelas potências mundiais, Estados Unidos e União Soviética, o interesse primordial estava em criar sistemas de alianças. O tema de assistência aos países massacrados pela guerra, já começava a ser debatido pela comunidade internacional, principalmente pelos Estados Unidos. A ajuda primordial era para os países Europeus, o que veio posteriormente como premissa de inserir esses países no novo contexto mundial. Contudo, é importante ressaltar que a assistência a esses países foi introduzida estrategicamente diante dos Estados Unidos, para promover ideologicamente e conduzir o distanciamento do comunismo soviético dos países capitalistas ocidentais (CERVO, 1994; MARTINUSSEN e PEDERSEN, 2003 ).

Em 1947, os Estados Unidos da América criou um plano para a reconstrução dos países aliados da Europa. O Plano Marshall ${ }^{2}$ injetou bilhões de dólares nas economias dos países europeus. Logo a reconstrução desses países foi imediata, tendo em quatro anos, a reconstituição econômica de diversos países da Europa. A distribuição e a coordenação de todos os fundos disponíveis pelo Plano Marshall foi coordenada pela Organização Europeia de Cooperação Econômica (OECE), em que, também, influenciaram na criação de zonas de comércio livre, uniões aduaneiras e a cooperação entre os países membros

\footnotetext{
2 Iniciativa americana que recebeu o nome do Secretário Geral dos Estados Unidos.
} 
europeus e os Estados Unidos (CERVO, 1994; MARTINUSSEN e PEDERSEN, 2003 ).

A proposta de reconstrução americana abrangeu para diversos outros países do mundo, porém, com menos recursos financeiros. O presidente Truman, apresentou ao congresso americano o primeiro plano para a expansão econômica dos Estados Unidos, para isso criou o fundo para o desenvolvimento, com contrapartida em combater a ameaça comunista. Assim, países asiáticos como Taiwan e Coréia do Sul, foram os primeiros a receberem apoio econômico dos EUA. Em seguida, os países Latinos Americanos e os da África (MARTINUSSEN e PEDERSEN, 2003).

Todavia, em 1948, começou a emergir uma das primeiras iniciativas de estruturação da cooperação mundial (tanto tecnológica, científica e financeira) em que foi impulsionada pelas Nações Unidas. Em 1948, a expressão assistência técnica ${ }^{3}$, passou a ser instituída pela Assembleia Geral das Nações Unidas, o que levou a lançar seu primeiro programa multilateral para 0 terceiro mundo ${ }^{4}$, em detrimento do Primeiro Programa de Cooperação Técnica Bilateral dos Estados Unidos para os países subdesenvolvidos. A premissa das Nações Unidas era de construir uma nova ordem econômica global, reforçando a assistência aos diversos países subdesenvolvidos e utilizando a Cooperação Técnica Internacional para todos os fins ideológicos e econômicos (CERVO, 1994).

Ainda nos anos 50, o mundo sofria com a pobreza e começava capacitação para o desenvolvimento por todos os Estados. Fora que, neste período, os países fora do contexto de guerra fria começaram a expor reações negativas em referência ao sistema bipolar e a nova divisão das regiões em zonas de influências. O principal fator estava na condição dos países atrasados, em que

\footnotetext{
${ }^{3}$ A expressão "assistência técnica" foi instituída, em 1948, pela Assembléia Geral das Nações Unidas, que a definiu como a transferência, em caráter não comercial, de técnicas e conhecimentos, mediante a execução de projetos a serem desenvolvidos em conjunto entre atores de nível desigual de desenvolvimento, envolvendo peritos, treinamento de pessoal, material bibliográfico, equipamentos, estudos e pesquisas. (Resolução 200 da Assembleia Geral das Nações Unidas).

4 Termo utilizado até os ano 1990, para designar os Países neutros na guerra fria e os países pobres do Sul. Entretanto, este termo tornou-se em desuso.
} 
começaram a exigir do sistema internacional condições mais favoráveis para o desenvolvimento e repudiaram a divisão ideológica do mundo. Sendo assim, a partir das inferências dos estados, a noção de cooperação internacional modernizou-se e, em 1959, o termo foi revisto e substituído para cooperação técnica ${ }^{5}$ (CERVO, 1994 ).

Com isso, nos anos sessenta, foram marcados pela maior capacitação mútua dos Estados, tanto os desenvolvidos quanto aos em desenvolvimento, para o fornecimento da cooperação técnica internacional, sendo prerrogativa das partes definir as premissas da cooperação e agregar novas funções de acordo com seus interesses. Os chamados países do Norte adotaram a postura de desenvolvidos, e os países do Sul consagraram-se como países subdesenvolvidos ou em desenvolvimento. Esta linha divisória do mundo passou por constantes mudanças ao longo das décadas, tendo no século XXI maior embasamento dos parâmetros desse novo contexto estatal econômico.

Foi apenas, a partir da década de 1970, que o termo cooperação sul-sul, passou a existir entre os países em desenvolvimento. A cooperação técnica para países em desenvolvimento teria como premissa ser uma alternativa a alianças assimétricas, por alianças mais alinhadas e horizontais. Assim, os países do Sul deveriam cooperar entre si a fim de garantir reformas políticas globais, esforços comuns, resolver problemas sociais com base de identidade compartilhada, na interdependência e na reciprocidade (MILANE e CARVALHO, 2012).

Foi neste contexto que as relações Brasil-China começaram a emergir com mais força e intensidade. $O$ fortalecimento das relações bilaterais entre os países foi impulsionada pela deterioração da relação dos chineses com os soviéticos e pela melhoria das relações da China com os Estados Unidos. $\mathrm{Na}$ década de 1970, o Brasil e a China convergiam em boa parte dos temas internacionais. Os dois países recusavam-se a assinar o Tratado de Não Proliferação de Amas Nucleares, pois o consideravam discriminatório; ambos

\footnotetext{
${ }^{5}$ O termo"cooperação técnica" era propício para definir uma relação que, se por um lado pressupõe a existência de partes desiguais, por outro representa uma relação de trocas, de interesses mútuos entre as partes.
} 
possuíam interesses econômicos e políticos horizontais, afim de construir uma agenda comum aos países do eixo Sul-Sul; partilhavam da necessidade de uma Nova Ordem Econômica Mundial que incluíssem os Estados em desenvolvimento e não apenas os já desenvolvidos. A criação deste laço a partir da perspectiva Sul-Sul, foi o marco para o início da cooperação Sul-Sul entre os dois países. Sendo que a década de 1980, foi um período de diversos acordo de cooperação técnica tendo o desenvolvimento mútuo (LEITE, 2011).

Com isso, o termo Sul-Sul passou a ser inserindo na comunidade internacional. Vários Estados, em linha de desenvolvimento, passaram a utilizar de tal conceito em prol do seu crescimento. A criação de cooperação técnica entre esses Estados demonstrou grandes ganhos, conseguindo, em alguns casos, diminuir com a dependência que se atrelaram aos Estados desenvolvidos. A criação de vários arranjos, como os BRICS, foi outra consequência deste quadro. Desse modo, a comunidade internacional passou a se dinamizar e consagrar-se entre vários polos, enfatizando, principalmente, o lado econômico.

\section{e) Cooperação Brasil-China}

Em relação a cooperação sino-brasileira, principalmente no âmbito técnico e político, diversos autores relatam a década de 1980 como um grande motivador para aproximação entre os países, com o intuito ao desenvolvimento mútuo. Porém, como relatado por Oswaldo Biato (2010), é importante citar a criação das comissões mista Brasil-China, em 1978, que influenciou na cooperação técnica para o desenvolvimento de energia entre as estatais brasileiras e as empresas chinesas de energia.

A cooperação política demonstrou fortalecimento para a aproximação na década de 1980. Como colocado por Henrique Altemani (2004), os interesses dos países para a construção de uma agenda política comum, tendo em vista os países do eixo Sul-Sul, impôs a aproximação bilateral nos temas de política externa para os anos posteriores. Este argumento valida o relato, em um outro artigo acadêmico do mesmo autor, o qual expõe a maior aproximação dos 
Estados, tendo em vista a assinatura de diversos acordos culturais, em 1986 (2006).

Danielly Becard (2011), também traz a perspectiva política como um dos maiores marcos para o início das relações sino brasileira. Relata a primeira viagem oficial do Brasil à China onde foram assinados vinte atos bilaterais, incluindo acordos na área de energia nuclear, cooperação cultural e educacional. Já no entendimento de Sérgio Lima (2016), a visita do Presidente José Sarney foi a precursora para a o estabelecimento das relações entre os países, a assinatura da cooperação técnica espacial para a produção conjunta de satélites, foi de extrema relevância.

Já na década de 1990, é perceptível a oscilação das relações políticas e de cooperação técnica. Altemani (2004) destaca que acontece um hiato entre as relações dos países durante o Governo Collor, apenas retornando o fortalecimento das relações em 1993, quando são assinados diversos acordos de cooperação bancária e de energia, sendo realizadas diversas visitas oficiais. Contudo, devido ao apoio brasileiro as novas prerrogativas de Direitos Humanos na ONU colocada pelos Estados Unidos, torna-se uma consequência para o distanciamento entre os países, como colocado por Oswaldo Biato (2010).

A partir dos anos 2000 impõe-se a criação de novas atividades de cooperação técnica com o Brasil, principalmente em cooperações de grande interesse próprio. Assim, as proposições de Biato (2010), Lazarrini e Bourgeois (2010) denotam o grande interesse chinês pela tecnologia de montagem de aviões da empresa brasileira EMBRAER, criando uma joint venture com uma empresa chinesa de aviões AVIC II.

Neste período também houve o fortalecimento das relações políticas sinobrasileiras. Como colocado por Holanda (2016), foi em 2004 que se deu a criação de diversos organismos, comissões mistas e os sucintos interesses brasileiros na implementação das agendas Brasil-China.

Com isso, torna-se claro as oscilações e o crescimento da relação comercial passando a influenciar nos âmbitos da cooperação técnica, 
principalmente no século XXI. È perceptível a mudanças nos interesses chineses a partir dos anos 2000 sob o Brasil, por vias da cooperação para o desenvolvimento.

\section{f) Relação Comercial Brasil-China}

Existem diversos estudos que tratam da relação comercial Brasil-China. Autores como Oswaldo Biato (2010) e Henrique Altemani (2012) expressão a aproximação comercial dos países através do comercio de açúcar na década de 1980. Já Becard (2011), retorna nos anos 1970 demonstrando ênfase na assinatura do primeiro Acordo Comercial.

Ainda em 1980, a principal pauta exportadora brasileira para China era constituída por produtos com alto valor agregado. No caminho inverso, o Brasil importava da China apenas petróleo, como colocado por Becard (2011) e Biato (2010). Este período também é marcado pelas oscilações no intercâmbio comercial, tendo grande crescimento em 1985 e baixas no final da década de 1980.

Jenkins (2012) evidencia neste período a mudança da pauta exportadora brasileira. Grande parte das exportações brasileiras são de produtos de baixo valor agregado. Em contrapartida, a China começa a exportar diversos produtos de grande valor agregado. Melucci e Oliveira (2012), colocam a expansão das estruturas internas feitas pelo Governo Comunista Chinês como uma das consequências para a transformação da pauta exportadora.

Os anos 2000 foram marcados pelo intenso crescimento do comércio bilateral entre o países. Como colocado pelo IPEA (2011), as exportações do Brasil para a China apresentou crescimento superior à elevação do comércio do Brasil com o mundo, sendo perceptível o crescimento da corrente comercial. A China, em 2009, torna-se o principal parceiro comercial do Brasil, enquanto que 0 Brasil em 2015, foi considerado o sétimo principal parceiro comercial da China.

Dessa forma, é visível o amadurecimento das relações entre os países apenas a partir dos anos 2000. O Brasil possui sua principal pauta de exportação 
constituída apenas por commodities, já a China exporta grande quantidade de máquinas, brinquedos e celulares. Estes fatores retomam a perspectiva teórica da constituição de um Centro, formado pela China, e por uma Periferia, constituída pelo Brasil. 


\section{METODOLOGIA}

Após o ínicio do trabalho observou-se a necessidade do aprimoramento da metodologia, tendo em vista a profundidade que foi dada à pesquisa. Assim, foi adotada a abordagem qualitativa o que permitiu uma melhor interpretação dos fatos. Levando em consideração a perspectivia teórica do sistema mundo, sendo possivel utilizá-la em diversas análises em periodos distintos devido a constante mudança da estrutura mundial, foi possivel realizar uma interpretação das relações comerciais e de cooperação entre o Brasil e a China. Para isso, optou-se pelo método de estudo de caso, histórico e de Interpretação adotado como estratégica na pesquisa. Sendo possível analisar documentos oficiais, pesquisa em banco de dados governamentais, bibliografias históricas e teóricas.

Nos dois primeiros meses da pesquisa, pensou-se que a teoria da dependência poderia fornecer maior embasamento para o sistema mundo. Contudo, após a revisão bibliográfica de autores como Theotonio dos Santos, percebeu-se que a leitura crítica marxista não estaria de acordo com o que foi proposto pelo projeto. A enfase dada pela Teroria da Dependência no desenvolvimento industrial dos países latino-americanos, acabando na super exploração pelos paises Centrais, não estaria de acordo com a relação de cooperação técnica sino-brasileira. Fora que as características colocadas aos países centrais e períféricos, teria como ponto de partida a dependência, a China ainda pode ser caracterizada como um país periférico, principalmente por conta da sua grande população na qual boa parte ainda vive em condições precárias, o que pode ser assimilado ao Brasil.

Posteriormente, sendo o instrumento da pesquisa na análise das relações sino-brasileiras, foi revisada a bibliografia consoante da teoria do Sistema Mundo e os conceitos de cooperação Norte-Sul e Sul-Sul. Num primeiro momento foi descrito e contextualizado todo o arcabouço teórico do Sistema Mundo. O que de fato validou a análise e interpretação da relação comercial e de cooperação bilateral, partindo do pessuposto do Sistema Mundo Moderno, onde a esfera econômica mundial capitalista é divida por camadas: Centro, Semiperiferia e Periferia. Logo, o contexto histórico dos conceitos da cooperação Sul-Sul e Norte- 
Sul foram fundamentais para entender a o início das relações entre os países e como houve uma mudança de perspectiva para a cooperação, baseada em interesses econômicos. Sendo possível, primeiramente, constatar uma possível verticalização da relação entre os países, caracterizando uma relação no sistema mundial do século XXI, de Centro e Semiperiferia.

O estudo de caso e o método histórico foram de suma importância para atender a estutura total dessa pesquisa. Com isso, foram coletadas diversas informações sobre as relações entre os países e foi observado certa horizontalidade entre o século XX e XXI. É percepitivel, no início das relações sino-brasileiras, o engajamento na cooperação técnica tendo resultados positivos para ambos os países e as assimilações no âmbito de política externa o que fornceu a base para aproximação, porém, nota-se através dos estudos em documentos oficiais e tabelas de intercâmbio comercial fornecida por instituições governamentais o fortalecimento no quadro comercial a partir dos anos 2000, o qual transformou toda a relação bilateral até então podendo ser interpretada pela perspectiva Sul-Sul. Desse modo, a pesquisa foi dividida em duas partes entre os anos 1964-2000 e 2001-2015, com o intuito de responder com maior coerência à questão central da pesquisa.

Isto posto, compreendendo melhor as relações comerciais, políticas e de cooperação técnica entre o Brasil e China, a pesquisa conseguiu analisar, a partir da revisão bibliográfica do Sistema mundo, com maior clareza e intensidade se houve ou nao uma verticalização na relação Brasil-China. 


\section{RESULTADOS}

\section{Distanciamentos e aproximações: A Cooperação Bilateral Brasil-China (1964-2000)}

Como colocado pela Teoria do Sistema Mundo, a estrutura internacional desigual de Estados é a que mantém toda a divisão internacional do trabalho, o que os torna responsáveis pelo acúmulo de riquezas dos Estados capitalistas já desenvolvidos, ocasionando, consequentemente, no subdesenvolvimento dos demais. Foi justamente nesse sentido que a relação brasileira com a China, começou a se fortalecer. A decada de 1964, foi marcada pela forte aproximação entre os dois hemisférios, graças aos interesses na construção de uma agenda política comum a países em desenvolvimento, tentando distanciar da ajuda disponibilizada pelos países desenvolvidos, e em um inicial processo de instauração dentro da economia mundial.

Nesse sentido, o Brasil e a República Popular da China possuíam algumas similaridades em alguns princípios de política externa, como a determinação em assegurar a autonomia de sua soberania, a integridade territorial, opondo-se a qualquer tipo de interferência nos assuntos internos de outros países e no jogo de política externa hegemônica imposta pelos Estados Unidos da América (OLIVEIRA, 2006).

Neste período os conceitos de perspectiva Sul-Sul, começam a se inserir com maior força e clareza no sistema e os Estados, como o Brasil e China, passam a construir eixos comuns para o desenvolvimento mútuo, como resposta à perspectiva Norte-Sul. Sendo assim, após a instalação da ditadura militar no Brasil, houve um impasse na relação sino-brasileira que perpetuou-se por dez anos, quando então no governo do Presidente Geisel (1974-1979) foi adotado maior flexibilidade ideológica, advinda da observação do Itamaraty na aproximação dos Estados Unidos com a República Popular da China e a recuperação de seu assento no conselho de segurança das Nações Unidas ${ }^{6}$ em

\footnotetext{
${ }^{6}$ Até então liderada por Taiwan.
} 
1971, fez com que os chineses fossem recebidos em uma missão comercial para a compra de açúcar no Brasil (BIATO, 2010).

Contudo, devido a crise que se passava naquela época no cenário internacional e a grande dívida externa brasileira, colaborou para que o Governo brasileiro superasse as desconfianças nos chineses, devido a ideologia anticomunista, com intuito de aumentar sua pauta exportadora e por outro lado o país asiático começava a demonstrar maiores esforços na modernização e abertura de sua economia para o âmbito externo. Assim, é a partir de 1978, com o aumento do intercâmbio comercial entre os países focada na exportação brasileira de açúcar e importação de petróleo chinês, que analisando sob ótica do Sistema Mundo Capitalista Moderno começa a atenção especial pelos empresários e os detentores de poder político, devido a pluralidade de Estados, na zona de interesses ou vantagens absolutas comerciais, o que se intensifica a partir dos anos 1990, na relação bilateral (LEITE, 2011).

A partir disso, foi assinado o primeiro Acordo Comercial ao qual seria um Convênio de Transportes Marítimos que visava abranger a oferta de serviços (BIATO, 2010). Neste mesmo período a corrente comercial começou a subir, indo de US\$19,4 milhões, em 1974, para US\$ 202 milhões, em 1979. A principal pauta de exportação chinesa era em produtos primários como o algodão, açúcar e farelo de soja, enquanto que elementos químicos e farmacêuticos foram os produtos chineses importados pelo Brasil. Outro componente importante que começava a configurar o quadro comercial dos países, era a importação de petróleo chinês pelo Governo brasileiro (BECARD, 2011).

O incremento de participações de estatais brasileiras, como a Petrobras, Sidebrás e Companhia Vale do Rio Doce CVRD, forneceu algumas reuniões da Comissão Mista Comercial, previstas no Acordo Comercial de 1978, o que demonstrou maior endurecimento, de fato, nos avanços bilaterais de perspectiva Sul-Sul, na década de 1980, já que essas comissões mistas foram realizadas em 1980, 1982 e 1984, tendo como objetivo dirigir o comércio para setores que as 
partes possuíam interesses mútuos, com o intuito de uma agenda comum, tendo em vista os dois países estando na totalidade Perférica (BIATO, 2010).

A partir da década de 1980, o Brasil tentava se reintegrar no comércio e na política internacional de maneira mais incisiva, com a transição do regime militar para a democracia, o que foi marcado por uma grande crise. Por outro lado, a China realizava constantes reformas econômicas internas e começava investir no desenvolvimento da abertura comercial no âmbito internacional, o que denota a inserção dentro da estrutura mundo, que passava por transformações e a necessidade desses Estados se inserirem Pois possuía interesses econômicos na América Latina, principalmente na importação de produtos industrializados, para o próprio desenvolvimento e por conta da nova premissa que se instaurava na comunidade internacional de aproximação entre os países do Sul optando por não rivalizar com as grandes potências (relação entre o Centro e Periferia) e avançar nos projetos de modernização, o que demonstrou ênfase na horizontalidade a partir da cooperação Sul-Sul, sendo um processo que pudesse the trazer vantagens (BECARD, 2011).

A partir de 1984, o Brasil começou a expandir fortemente suas exportações para a China, suprindo a enorme demanda chinesa por insumos industriais. O que de fato se concentrou na exportação de US\$83 milhões em produtos siderúrgicos, US $\$ 39$ milhões em materiais plásticos artificiais, US $\$ 15$ milhões em fios de fibras têxteis e US\$ 3 milhões em produtos químicos orgânicos. Logo, as importações brasileiras eram totalmente voltadas para o petróleo chinês, o que consequentemente, gerou saldos favoráveis ao Brasil de US\$ 80 milhões em 1983 e US\$ 400 milhões em 1985 (BIATO, 2010) como exposto na tabela abaixo:

TABELA I: PAUTA DE EXPORTAÇÃO DO BRASIL PARA A CHINA 


\begin{tabular}{|cccc} 
Ano & $\begin{array}{c}\text { Export. Básicos/ } \\
\text { Export. totais }\end{array}$ & $\begin{array}{c}\text { Export. } \\
\text { Semi-manufaturados/ } \\
\text { Export. totais }\end{array}$ & $\begin{array}{c}\text { Export. } \\
\text { Manufaturados/ } \\
\text { Export. totais }\end{array}$ \\
\hline 1985 & $6,0 \%$ & $30,1 \%$ & $63,9 \%$ \\
\hline 1986 & $10,1 \%$ & $39,5 \%$ & $50,4 \%$ \\
\hline 1987 & $21,5 \%$ & $28,0 \%$ & $50,5 \%$ \\
\hline 1988 & $17,1 \%$ & $14,0 \%$ & $68,9 \%$ \\
\hline 1989 & $11,7 \%$ & $27,5 \%$ & $60,8 \%$ \\
\hline 1991 & $19,6 \%$ & $48,8 \%$ & $31,5 \%$ \\
\hline
\end{tabular}

FONTE: BIATO, 2012 ( MIDC/SECEX)

TABELA II: IMPORTAÇÕES BRASILEIRAS VINDAS DA CHINA EM 1986 E 1991

\begin{tabular}{lrrrrrr} 
& \multicolumn{2}{c}{$\mathbf{1 9 8 6}$} & & \multicolumn{2}{c}{1991} \\
\cline { 2 - 3 } \cline { 6 - 6 } Produto & Valor & Participação(\%) & & Valor & Participação(\%) \\
\hline Petróleo bruto & 254 & 88,1 & & - & - \\
Sementes de mamona & 5 & 1,8 & & - & - \\
Óleo de menta arvensis & 4 & 1,7 & - & - \\
Carvão mineral & - & - & 4,6 & 7,4 \\
Óleos de rícino & - & - & 1,4 & 2,2 \\
\hline Outros & 26 & 8,4 & 56 & 90,4 \\
\hline Total & $\mathbf{2 8 9 , 0}$ & $\mathbf{1 0 0 , 0}$ & & $\mathbf{6 2 , 0}$ & $\mathbf{1 0 0 , 0}$
\end{tabular}

FONTE: BIATO, 2010 (CACEX/DEPEC) Valor em U.S MILHÕES F.O.B

Neste mesmo espaço de tempo, nota-se, visualizando a Tabela I e II, que pauta a exportadora brasileira se aproveita do relativo atraso industrial chinês e concentrou-se, também, em produtos industrializados. O que de fato Contribuiu para isso a industrialização e o investimento na estrutura ferroviária brasileira apoiada pelos militares. $\mathrm{O}$ qual pode se configurar em uma relação entre Centro e Periferia, porém, pelas características atreladas aos Estados centrais so o ponto de vista do Sistema Mundo Moderno, o Brasil não adequava-se a nenhuma. O intuito brasileiro neste período estava em criar fontes para a cooperação técnica e comercial com países que se alinhavam-se e demonstravam certa horizontalidade e equilíbrio. Claro que sempre observando seus interesses comerciais a partir da pluridade de estados que se integrava dentro da nova divisão internacional do trabalho que se concretizava como uma estrutura de sistema mundo moderno. 
Portanto, os acordos em diversas áreas científicas e tecnológicas e as visitas políticas foram outros fatores que ofereceram maior embasamento para a relação mútua. Ao longo dos anos 80 , foram assinados cerca de 20 atos bilaterais com a China, tendo em vista o desenvolvimento a partir da cooperação de países da periferia. Os acordos incluiam as áreas pouca desenvolvidas pelos estados, como de energia nuclear, cooperação cultural e educacional. A viagem do Presidente João Figueiredo, em 1984, sendo a primeira viagem de um chefe de Estado durante o regime militar à China,foi de suma importância para tal feitio.

Esta década, também, pode se caracterizar pelo início das cooperações técnicas. A viagem do Presidente José Sarney, em 1988, foi importante e teve como fruto o acordo espacial do "Protocolo de Pesquisa e Produção Conjunta de satélites Sino-Brasileiros de Recursos Terrestres" (CBERS). O principal objetivo da assinatura do acordo estava em fugir das imagens obtidas pelos países do Centro, como os Estados Unidos, favorecendo o desenvolvimento tecnólogico. O acordo foi considerado o maior projeto de alta tecnologia assinado até então entre dois países que se encontravam em linha de desenvolvimento, demonstrando um novo modelo de cooperação "Sul-Sul" (BIATO, 2010 apud LIMA, 2016). A parceria espacial foi considerada um sucesso para ambos os países. A China e o Brasil ingressaram no seleto grupo de Estados detentores da tecnologia de geração de dados sensoriais remotos.

Primeiramente, foram lançados dois satélites, o CBERS 1 e 2, que alcançaram sucesso pelo foguete chinês de longa marcha, produzindo o perfeito funcionamente dos satélites na órbita. Graças ao sucesso dos dois primeiros satélites, foi decidido entre os dois Governos, o lançamento de mais três satélites, sendo o ultimo lançado em 2014. As imagens coletadas pelos satélites são usadas em diversos campos importantes, principalmente no desmatamento da Amazônia e nas áreas agrícolas brasileiras (CBERS, 2014). Neste ponto fica claro, o enfoque no desenvolvimento em iniciativas de cooperação técnica com características consideradas de perspectiva Sul-Sul. 
Todavia, é a partir da década de 1990, que as relações comerciais começam a se concretizar com algumas relativas mudanças. O que se enquadra diante da perpectiva trazida por Wallerstein (2004), na mudança do quadro entre 0 Centro e a Semiperiferia, começando uma talvez verticalização no quandro da relação. Contudo, é principalmente, a partir, dos anos 2000 que esse quadro se concretiza e passa a influenciar todas a negociações no âmbito de cooperação bilateral.

Entre 1991 e 1995 houve crescimento de cerca de 600\% no intecâmbio comercial entre os países. As exportações brasileiras para a China passaram de US\$ 226 milhões para US\$1,2 bilhão, enquanto que as importações da China tiveram um aumento, passando de US\$ 129 milhões para US\$1,04 bilhão. Pelo viés chinês, o grande crescimento econômico, trouxe, consequentemente, a melhoria dos padrões alimentares, aumentando a demanda por produtos agroindustriais brasileiros, como óleo de soja e açúcar. Logo, as participações brasileiras nas exportações para a China passam de 0,7\% (1991) para 2,6\%, enquanto que como proporção total das importações brasileiras à China passou de $0,6 \%$ para $2,1 \%$ (BIATO, 2010). A partir desse período, percebe-se nova configuração da pauta exportadora chinesa para o Brasil, muito constituída por produtos industrializados. Tal efeito é direcionado graças ao rápido desenvolvimento industrial chinês, o qual já possuía sua pauta de exportação constituída de artigos de couro, calçados, têxteis e confecções, brinquedos e artigos eletrônicos simples, e já se revelava como um novo grande competidor para o Brasil. Como exposto nas tabelas abaixo:

TABELA III: BRASIL PRINCIPAIS PRODUTOS IMPORTADOS DA CHINA (1993 a 1995) 


\begin{tabular}{lrrrrrr}
\multirow{2}{*}{ Descrição } & \multicolumn{2}{c}{1993} & \multicolumn{2}{c}{1994} & \multicolumn{2}{c}{1995} \\
& Valor & Part.\% & Valor & Part.\% & Valor & Part\%. \\
\hline Máq. e aparelhos elétricos & 56,7 & 18,6 & 119,0 & 25,7 & 192,4 & 18,5 \\
Brinquedos e jogos & 7,3 & 2,4 & 24,7 & 5,3 & 103,3 & 9,9 \\
\hline Produtos químicos orgânicos & 44,5 & 14,6 & 52,6 & 11,3 & 91,6 & 8,8 \\
\hline Vestuário & 2,4 & 0,8 & 12,7 & 2,7 & 73,3 & 7,1 \\
\hline Caldeiras/ instrumentos mecânicos & 45,2 & 14,8 & 39,4 & 8,5 & 69,6 & 6,7 \\
\hline Calçados & 7,4 & 2,4 & 22,4 & 4,8 & 67,4 & 6,5 \\
\hline Carvão de coque & 33,0 & 10,8 & 36,3 & 7,8 & 57,0 & 5,5 \\
\hline
\end{tabular}

FONTE: BIATO, 2010 (MDIC/SECEX)

A alteração na pauta exportadora brasileira é bastante significativa nesse período, o que pode ser constatado, de maneira comparativa, nas tabelas I e IV. O que se concentrava em produtos manufaturados e semimanufaturados na década de 1980, transformou-se, surpreendentemente, na venda de poucos produtos, quase todos primários na década de 1990 (BIATO, 2010).

TABELA IV: PAUTA DE EXPORTAÇÃO DO BRASIL PARA A CHINA (1993 a 1995)

\begin{tabular}{lrrrrrr}
\hline \multirow{2}{*}{ Descrição } & \multicolumn{2}{c}{1993} & \multicolumn{2}{c}{1994} & \multicolumn{2}{c}{1995} \\
& Valor & Part.\% & Valor & Part.\% & Valor & Part\%. \\
\hline Óleo de Soja & 11,0 & 1,4 & 416,9 & 50,7 & 550,9 & 45,8 \\
Minério de ferro & 112,8 & 14,5 & 130,4 & 15,9 & 155,9 & 13,0 \\
\hline Açúcar & 0 & 0 & 0 & 0 & 112,3 & 9,3 \\
\hline Ferro fundido, ferro, aço & 532,3 & 68,3 & 175,3 & 21,3 & 96,5 & 8,0 \\
\hline Autopeças & 1,8 & 0,2 & 0,8 & 0,1 & 68,2 & 5,7 \\
\hline Caldeiras/instrumentos mecânicos & 37,2 & 4,8 & 21,5 & 2,6 & 47,6 & 4,0 \\
\hline Máq., aparelhos elétricos & 1,7 & 0,2 & 2,7 & 0,3 & 27,4 & 2,3 \\
\hline
\end{tabular}

FONTE: BIATO, 2010 (MDIC/SECEX)

Consta-se que esta nova prerrogativa econômica, diante da ótica teórica do novo sistema mundo capitalista, sofre constantes transformações, bastou aos Estados se inserirem nesta nova divisião internacional do trabalho. Posto isso, a economia mundial é um constante emaranhado de políticas estatais e de âmbito privados e devem ser impulsionados pelos próprios Estados, já que estes são considerados um dos principais agentes na nova configuração do sistema. Sendo assim, a China conseguiu desenvolver, de forma impressionante, a sua indústria. A década de 1980 foi de extrema importância para que houvesse o incentivo do 
Governo na industrialização. A rápida industrialização demonstrou resultados na década de 1990, conseguindo gerar um setor industrial mais moderno, eficiente e competitivo internacionalmente. Tal fato torna a China, no sentido comercial, capaz de conter características de países do Centro, fato que pode ser considerado como consequência da convergência global atual, muito devido à globalização, sendo um fator da nova conjuntura do sistema mundo moderno. Diferentemente do Brasil, que não induz o justo investimeto no setor industrial acabando por não inovar sua produção e se caracteriza por manter um comportamento de Estado semiperiférico, diante das dificuldades em dinamizar sua indústria interna. Este âmbito econômico demonstra a contradição em manter a relação entre os países numa perspectiva horizontal. Portanto, a transformação no quadro de exportações e importações dos países demonstra o grande avanço industrial Chinês, para então torna-se um país com algumas características de centro, e a estagnação brasileira tendo crescido em poucos setores industriais e com a retomada da pauta agrícola, que perpetua até os dias atuais.

Por conseguinte, em 1998, as relações comerciais despencaram. Desde os anos 1995-1997, as relações comerciais entre os países eram mantidas em US $\$ 2,2$ bilhões, porém, em 1998, cai para $R \$ 1,54$ bilhões, tendo o Brasil na sua maior pauta de exportação os produtos primários, o que pode ser demonstrado diante das tabelas $\mathrm{V}$ e VI. Vários motivos foram apontados como causadores dessa nova oscilação econômica. A crise financeira asiática fez com que as exportações chinesas à Ásia, seu maior mercado importador, se reduzisse. O que rapidamente atingiu o Brasil, principalmente pela taxa de câmbio, conduzindo a flutuação do real consequentemente a desvalorização da moeda brasileira. Outro fator que teve grande impacto restritivo nesse âmbito comercial foi a observação brasileira no quesito da reestruturação comercial com a China, onde observa-se a concretização de um tipo de relacionamento vertical entre os países, influenciando nos projetos de cooperação sino-brasileiro, em que o Brasil fornece produtos que funcionam como matéria prima enquanto que Pequim exporta para o Brasil produtos de valor mais agregado. É importante notar que neste período os chineses já possuíam grande demanda de produção em mão de obra com 
equipamentos sofisticados, deixando para trás sua principal pauta exportadora de commodities como o Petróleo, da década de 1980. Dessa forma, o Brasil passou a aplicar medidas restritivas às importações chinesas, principalmente na área têxtil e de brinquedos, respondendo a uma grande demanda de empresários nacionais que reclamavam da grande demanda de consumo dos brasileiros desses produtos chineses, que possuíam um valor mais barato. O Brasil também pleiteou, dentro da Organização Mundial do Comércio, a redução tarifária de vinte produtos de seus interesses, anos depois concedida pela China (BIATO, OLIVEIRA 2010, 2004).

TABELA V: PAUTA DE EXPORTAÇÃO DO BRASIL PARA A CHINA (1997 A 1999)

\begin{tabular}{lrrrrrr}
\multicolumn{1}{c}{ Descrição } & \multicolumn{2}{c}{1997} & \multicolumn{2}{c}{1998} & \multicolumn{2}{c}{1999} \\
& Valor & Part.\% & Valor & Part.\% & Valor & Part.\% \\
\hline Minério de ferro/concentrados & 179,4 & 16,5 & 199,7 & 22,1 & 242,1 & 35,8 \\
\hline Soja triturada & 89,2 & 8,2 & 221,6 & 24,5 & 111,3 & 16,5 \\
Pasta química de madeira & 34,1 & 3,1 & 24,0 & 2,7 & 52,6 & 7,8 \\
\hline Óleo de soja em bruto & 253,7 & 23,3 & 94,9 & 10,5 & 45,4 & 6,7 \\
\hline Fumo em folhas & - & - & 6,4 & 0.7 & 38,5 & 5,7 \\
Couros e peles & 13,7 & 1,3 & 15,2 & 1,7 & 21,4 & 3,2 \\
\hline Farelo de soja & 264,8 & 24,3 & 196,7 & 21,7 & 14,3 & 2,2 \\
Papéis fotográficos & 34,9 & 3,2 & 42,0 & 4.6 & 10,6 & 1,6 \\
\hline Aços laminados & 26,1 & 2,4 & 6,7 & 0,7 & 10,1 & 1,5 \\
\hline Ferro-ligas & - & - & - & - & 8,8 & 1,3 \\
\hline Veículos e autopeças & 13,8 & 1,3 & 11,8 & 1,3 & - & - \\
Polímeros etileno, propileno & 12,4 & 1.1 & - & - & - & - \\
\hline
\end{tabular}

FONTE: BIATO, 2010 (MDIC/SECEX)

TABELA VI: PRINICIPAIS PRODUTOS IMPORTADOS PELO BRASIL DA CHINA (1997 a 1999) 


\begin{tabular}{lrrrrrr} 
& \multicolumn{2}{c}{1997} & \multicolumn{2}{c}{$\mathbf{1 9 9 8}$} & \multicolumn{1}{c}{$\mathbf{1 9 9 9}$} \\
Descrição & Valor & Part.\% & Valor & Part.\% & Valor & Part.\% \\
\hline Aparelhos transmissores & 86,5 & 7,4 & 44,7 & 3,8 & 52,8 & 6,1 \\
\hline Brinquedos & 66,4 & 5,7 & 72,4 & 7,0 & 49,3 & 5,7 \\
\hline Carvão de coque & 68,5 & 5,9 & 87,1 & 8.4 & 37,1 & 4,3 \\
Compostos heterocíclicos & 29,7 & 2,5 & 31,1 & 3,0 & 34,2 & 4,0 \\
\hline Maquinas processamento dados & - & - & 44,2 & 4,3 & 32,9 & 3,8 \\
\hline Motores/geradores elétricos & 26,5 & 2,3 & 34,5 & 3,3 & 32,1 & 3,7 \\
\hline Partes de aparelhos vídeo e de som & - & - & - & - & 22,4 & 2,6 \\
\hline Compostos nitrogenados & - & - & - & - & 18,6 & 2,1 \\
\hline Calçados e componentes & 62,5 & 5,4 & 40,0 & 3,9 & 17,4 & 2,0 \\
\hline Toca-fitas & - & - & 23,4 & 2,3 & 15,4 & 1,8 \\
\hline Vestuário & 72,2 & 6,2 & 32,5 & 3,1 & - & - \\
Aparelhos eletromecânicos & - & - & 22,5 & 2,2 & - & - \\
Aparelhos de fotocópia & 32,0 & 2,7 & - & - & - & - \\
Aparelhos de telefonia & 23,5 & 2,0 & - & - & - & - \\
\hline Alho & 27,3 & 2,3 & - & - & - & - \\
\hline
\end{tabular}

FONTE: BIATO, 2010 (MDIC/SECEX)

Portanto, as relações sino-brasileiras desde 1964 a 1999, configuraram um quadro de oscilação tanto no âmbito político quanto no econômico. Os dois países desenvolveram grande paridade no quesito política externa, entretanto, não conseguiram desenvolver perspectivas econômicas igualitárias. O Brasil investe a todo custo seus expoentes estruturais urbanos e na fomentação tecnológica do campo rural, exportando, assim, para China grande quantidade de produtos manufaturados, no final da década de 1970 e final de 1980, tendo importado principalmente commodities do país Asiático, como Petróleo. Contudo, o rápido desenvolvimento industrial chinês dá margem para uma grande alteração na década 1990, o que é profundamente sentida pelo Brasil que passa a ter $75 \%$ de sua pauta exportadora de commodities. Esta nova configuração econômica dá margem a um eixo de cooperação vertical e, principalmente, invoca o fortalecimento da Parceria estratégica, marcada de interesses econômicos que acabam por influênciar nas decisões políticas e de cooperação, que virá nos próximos anos.

\section{A nova pauta: relações comerciais Brasil-China (2001-2015)}

A partir dos anos 2000, houve o amadurecimento da relação bilateral sino-brasileira, principalmente comercial. A evolução das relações entre Brasil e China, entre 2000-2010, apresentou crescimento superior à elevação do comércio 
entre Brasil e o mundo. Entre os anos 2000 a 2010, as exportações do Brasil para a China cresceram num valor aproximado de US $\$ 1,1$ bilhão, sendo $2 \%$ do total de toda a exportação do Brasil, para US\$30,8 bilhões transformando-se em 15\% do total das exportações brasileiras. Enquanto que as importações brasileiras da China passaram a configurar um total de 14\% (IPEA, 2011). No âmbito da política externa, os dois países passam a conduzir apoio mútuo em diversos temas da nova agenda internacional que se consagrava, porém a influência econômica sob a política se torna notória neste quesito.

Com a chegada do Presidente Luiz Inácio Lula da Silva, em 2003, muda o cenário de distanciamento político com a China. O novo Governo brasileiro decidiu em promover uma política de intensificação de diálogos políticos e econômicos "Sul-Sul". Neste período o intuito era em dar maior foco aos principais países emergentes do mundo em desenvolvimento, o que implicava em criar novas alianças estratégicas com a China, Rússia e Índia, e, ao mesmo tempo, fornecer maior fortalecimento aos organismos internacionais, como a Organização das Nações Unidas (ONU) e a Organização Mundial do Comércio (OMC).

Outra nova consonante na nova configuração da política externa, estava no intuito do Governo Lula em priorizar a integração dos Países da América do Sul. O objetivo era tornar o Brasil um novo global player através da integração do continente da América do Sul (OLIVEIRA, 2010).

Neste mesmo parâmetro constata-se a inserção chinesa no sistema mundo moderno. O país crescia em larga escala e se integrava cada vez mais no cenário internacional, principalmente no comércio mundial sob comando do líder máximo do partido Jiang Zemin (1993-2003). Dando continuidade à expansão chinesa a partir de 2003, o então novo Presidente da China Hu Jintao (2003-2013) alavanca a política e economia externa do país a um nível global. O regime comunista chinês aprofundou as bases de reformas do mercado e investiu na aproximação com diversos países do mundo, criando fóruns de debates empresariais sino-árabes e conquistando novos espaços estratégicos com países africanos. Na Europa o país retornou suas negociações com a França - 
embargada na década de 1990 devido à venda de material bélico a Taiwan. Com os Estados Unidos, em razão dos entraves feitos pelos americanos diante da alegada condução dos Direitos Humanos pelos chineses no final dos anos 1990, a partir do governo Clinton abandonou-se a tese de "confrontação" alterando-a para "engajamento", o que propiciou vencer as dificuldades de convivência entre a China e os Estados Unidos. Já na América Latina, a partir de 2003, a aproximação deu-se a partir da modernização baseada na industrialização intensiva chinesa, tendo como foco a busca por mercados, matérias primas e tecnologia, sendo elementos principais para o desenvolvimento chinês (BECARD, 2010; BIATO, 2011).

Logo, a primeira pauta colocada pelo Brasil em rodadas de negociação com a China, foi na criação de uma comissão bilateral que proporcionasse a dinamização e fortalecesse as comissões mistas setoriais de assuntos estratégicos que o Brasil possuía com a China, desde 1980. Assim, o governo Lula propôs a criação de uma comissão bilateral de Alto Nível e Coordenação (COSBAN), a ser presidida por altos funcionários governamentais, com o poder decisório em diversas áreas de cooperação (HOLANDA, 2016). O que fornecerá, mais tarde, grandes diálogos estratégicos sobre política e a agenda internacional.

Nota-se os grandes contornos em que foi demonstrado na política externa brasileira perante a comunidade internacional, com ênfase aos organismos internacionais e de diálogos, foi fortalecido pelo Brasil com a China. Na visita do Presidente $\mathrm{Hu}$ Jintao, o Presidente Lula reforçou a atuação conjunta dos dois países no G-207, na OMC e na ONU (BIATO, 2010). Organismos multilaterais de conversação tomaram força devido ao engajamento brasileiro em influenciar maior presença chinesa, como os BRICS (Brasil, Rússia, China, Índia e África do Sul) e o $\mathrm{G}-5^{8}$ (BECARD, 2011).

Em seguida, foram debatidos temas de grande interesse e sensibilidade para ambos os países. O Brasil possui grande interesse na candidatura para um

\footnotetext{
7 Grupo formado pelos ministros de finanças e chefes dos bancos centrais das 19 maiores economias do mundo mais a União Europeia.

8 Bloco dos cinco países em desenvolvimento (México, Brasil, China, Índia e África do Sul).
} 
assento permanente em uma eventual reforma do Conselho de Segurança das Nações Unidas, e busca na China o apoio para lograr êxito nesta tentativa. Por outro lado, os chineses desejavam que o Brasil os apoiasse no reconhecimento de que o país se transformara em "economia de mercado", deixando de ser uma "economia de transição". Contudo, não houve grandes avanços nesses temas. A China de forma genérica apoiou a entrada do Brasil como membro permanente, porém, se recusou a pronunciar-se publicamente. A desculpa da recusa estaria nas relações da China com outros países que também possuíam o mesmo desejo brasileiro. Enquanto que o reconhecimento do Brasil à China como economia de marcado foi concedido, meses depois, na viagem oficial do Presidente Hu Jintao ao Brasil (BIATO, 2010). Estes dois temas causaram grandes controvérsias nas relações sino-brasileiras.

Observa-se que o argumento favorável para ceder o status, estaria no fluxo de exportações chinesas para o mercado brasileiro o qual tornava-se intenso. As pressões por parte dos chineses também foram importantes para a tomada dessa decisão. Os chineses argumentavam impor eventuais retaliações que viessem a prejudicar as exportações brasileiras, como a redução de vantagens das indústrias brasileiras no comércio com a China (BIATO, 2010). O principal interesse da China estaria na influência do Brasil na região, sendo que os outros Estados vendo a atitude brasileira, também iriam ceder apoio à China. Todavia, considerar a China como economia de mercado teria efeitos no processo de investigação das medidas de dumping ${ }^{10}$, o que prejudicaria o Brasil no preço dos produtos importados que passariam a ser analisado de forma mais criteriosa, o que denotaria na perda das empresas nacionais brasileiras. Ora poder ser observado uma grande perda no setor econômico brasileiro, principalmente nos

\footnotetext{
${ }^{9}$ A Conferência das Nações Unidas sobre o Comércio e o Desenvolvimento (UNCTAD) define economia de mercado como a economia na qual as forças de mercado determinam, de maneira preponderante, os níveis de produção, consumo, investimentos e poupança sem intervenção do governo.

${ }^{10} \mathrm{~A}$ comprovação da existência de dumping, segundo as regras da OMC, se dá através da comparação do preço de exportação do produto para o país prejudicado com o valor normal do produto. (DE NEGRI, P 2 e 3).
} 
instrumentos para a defesa comercial industrial. (NEGRI e NETO, 2015; e PANZINE, 2002).

Dessa forma, torna-se, novamente, visível a alteração da perspectiva até então apresentada que se caracterizava como uma relação Sul-Sul. O fortalecimento econômico conseguiu influenciar no comportamento dos Estados no âmbito político, impactando em uma alteração da decisão até então colocada pelo Brasil, ocasionando uma flexibilização.

Nesse sentido, a visita brasileira à China foi composta por uma tripulação de cerca de quatrocentos empresários. O principal intuito estava em demonstrar a grande importância comercial que o Brasil visava conferir à China (BECARD, 2011). Ao mesmo tempo firmava-se a principal pauta exportadora brasileira para a China em produtos primários, minerais e recursos naturais, com pouco teor tecnológico, características de países semiperiféricos (GOUVEA e MONTOYA, 2013). Enquanto que a visão chinesa estava na assinatura de significativos novos acordos de cooperação técnica bilateral, já que estava longe de ser um grande destino para os capitais chineses considerando os investimentos diretos das empresas no exterior, que se destinam, em sua maioria, para países asiáticos e, principalmente, para economias já desenvolvidas (ROSITO, 2016).

Analisa-se que a partir de 2002 as exportações brasileiras para a China cresceram muito em comparação ao final da década de 1990. A China já se posicionava na quarta colocação do ranking brasileiro, sendo o maior importador do mercado brasileiro da Ásia, segundo dados do Ministério da Indústria, Comércio Exterior e Serviços,

TABELA VII: PRINCIPAIS PARCEIROS COMERCIAIS DO BRASIL 


\begin{tabular}{|c|c|c|c|c|c|c|c|}
\hline \multirow{2}{*}{ Ranking } & \multirow{2}{*}{ Principais Países } & \multicolumn{2}{|c|}{ Exportação } & \multicolumn{2}{|c|}{ Participação } & \multicolumn{2}{|c|}{ Variação } \\
\hline & & 2002 & 2001 & 2002 & 2001 & Absoluta & $\%$ \\
\hline 1 & Estados Unidos & 15.354 & 14.190 & 25,4 & 24,4 & 1164 & 8,2 \\
\hline 2 & Paises Baixos (Holanda) & 3.182 & 2.863 & 5,3 & 4,9 & 319 & 11,1 \\
\hline 3 & Alemanha & 2.537 & 2.502 & 4,2 & 4,3 & 35 & 1,4 \\
\hline 4 & China & 2.520 & 1.902 & 4,2 & 3,3 & 618 & 32,5 \\
\hline 5 & Mexico & 2.342 & 1.868 & 3,9 & 3,2 & 474 & 25,4 \\
\hline 6 & Argentina & 2.342 & 5.002 & 3,9 & 8,6 & -2660 & $-53,2$ \\
\hline 7 & Japao & 2.098 & 1.986 & 3,5 & 3,4 & 112 & 5,6 \\
\hline 8 & Bélgica-Luxemburgo & 1.892 & 1.812 & 3,1 & 3,1 & 80 & 4,4 \\
\hline 9 & Italia & 1.816 & 1.809 & 3,0 & 3,1 & 7 & 0,4 \\
\hline 10 & Reino Unido & 1.769 & 1.705 & 2,9 & 2,9 & 64 & 3,8 \\
\hline 11 & Franca & 1.525 & 1.648 & 2,5 & 2,8 & -123 & $-7,5$ \\
\hline 12 & Chile & 1.461 & 1.352 & 2,4 & 2,3 & 109 & 8,1 \\
\hline 13 & Rússia & 1.252 & 1.103 & 2,1 & 1,9 & 149 & 13,5 \\
\hline 14 & Espanha & 1.120 & 1.042 & 1,9 & 1,8 & 78 & 7,5 \\
\hline 15 & Coréia do Sul & 852 & 736 & 1,4 & 1,3 & 116 & 15,8 \\
\hline 16 & Venezuela & 797 & 1.092 & 1,3 & 1,9 & -295 & $-27,0$ \\
\hline 17 & Canada & 782 & 555 & 1,3 & 1,0 & 227 & 40,9 \\
\hline 18 & India & 654 & 285 & 1,1 & 0,5 & 369 & 129,5 \\
\hline 19 & Emirados Arabes Unidos & 653 & 440 & 1,1 & 0,8 & 213 & 48,4 \\
\hline \multirow[t]{2}{*}{20} & Colombia & 637 & 606 & 1,1 & 1,0 & 31 & 5,1 \\
\hline & Total & 60.362 & 58.223 & 100,0 & 100,0 & 2.139 & 3,7 \\
\hline
\end{tabular}

\section{Fonte: SISCOMEX}

Em 2001, volta o teor de cooperação técnica, contudo, os interesses dos países eram totalmente diferentes. $O$ intuito aqui não estava mais no desenvolvimento mútuo e sim no desenvolvimento próprio. Por isso, cria-se uma joint-venture entre a Companhia Vale do Rio Doce e a siderúrgica Baosteel, para o aprimoramento de fontes de energia. Em 2002, já se observa a demanda chinesa para o consumo de carne bovina e de frango sendo assinado, em seguida, um acordo de equivalência sanitária, abrindo as portas para exportação brasileira de carne bovina e de frango. Logo, foi assinada a parceria entre a Embraer e a empresa aeronáutica chinesa AVIC II. Com isso, é visível a contínua presença de produtos de baixo valor como a principal pauta exportadora do Brasil para a China, sendo em suma produtos agrários e de baixo valor agregado.

Entretanto, é importante notar a tentativa brasileira de diversificar a sua pauta exportadora para a China, sendo importante para as novas negociações de cooperação. $\mathrm{Na}$ maioria das tentativas de diversificação de produtos para exportação, o Brasil encontrou sérias dificuldades, principalmente em produtos considerados estratégicos pelo Governo chinês. Como no caso mais especifico, por ser tratar de um produto com alto teor tecnológico, a tentativa, de certo modo, 
frustrada da Embraer em exportar jatos para o país Asiático. Pode ser constatada a participação de aviões nas exportações brasileiras para China, na tabela VIII,

\section{TABELA VIII: PAUTA DE EXPORTAÇÃO DO BRASIL PARA A CHINA} (2001)

\begin{tabular}{|c|c|c|c|c|c|c|c|c|}
\hline \multirow[t]{2}{*}{ Ranking } & \multirow[t]{2}{*}{ Produtos } & \multirow[b]{2}{*}{2002} & \multirow[b]{2}{*}{2001} & \multicolumn{2}{|c|}{ Variação } & \multicolumn{2}{|c|}{ Part. \% } & \multirow{2}{*}{$\begin{array}{c}\text { Contribuição } \\
\%\end{array}$} \\
\hline & & & & Absoluta & $\%$ & 2002 & 2001 & \\
\hline 1 & Minérios de ferro & 3.049 & 2.932 & 117 & 4,0 & 5,1 & 5,0 & 5,5 \\
\hline 2 & Soja em grão & 3.032 & 2.726 & 306 & 11,2 & 5,0 & 4,7 & 14,3 \\
\hline 3 & Aviões & 2.335 & 2.839 & -504 & $-17,8$ & 3,9 & 4,9 & - \\
\hline 4 & Farelo de soja & 2.199 & 2.065 & 134 & 6,5 & 3,6 & 3,5 & 6,3 \\
\hline 5 & Automóveis de passageiros & 2.005 & 1.951 & 54 & 2,8 & 3,3 & 3,4 & - \\
\hline 6 & Apars.transmissores/recep. & 1.782 & 1.762 & 20 & 1,1 & 3,0 & 3,0 & 0,9 \\
\hline 7 & Petróleo em bruto & 1.691 & 721 & 970 & 134,5 & 2,8 & 1,2 & 45,3 \\
\hline 8 & Calçados & 1.516 & 1.684 & -168 & $-10,0$ & 2,5 & 2,9 & - \\
\hline 9 & Semimanuf. de ferro/aço & 1.410 & 1.081 & 329 & 30,4 & 2,3 & 1,9 & 15,4 \\
\hline 10 & Motores p/veículos & 1.341 & 1.112 & 229 & 20,6 & 2,2 & 1,9 & 10,7 \\
\hline 11 & Carne de frango & 1.335 & 1.292 & 43 & 3,3 & 2,2 & 2,2 & 2,0 \\
\hline 12 & Café em grão & 1.195 & 1.208 & -13 & $-1,1$ & 2,0 & 2,1 & - \\
\hline 13 & Celulose & 1.160 & 1.246 & -86 & $-6,9$ & 1,9 & 2,1 & - \\
\hline 14 & Autopeças & 1.159 & 1.172 & -13 & $-1,1$ & 1,9 & 2,0 & - \\
\hline 15 & Açúcar em bruto & 1.111 & 1.401 & -290 & $-20,7$ & 1,8 & 2,4 & - \\
\hline 16 & Açúcar refinado & 982 & 878 & 104 & 11,8 & 1,6 & 1,5 & 4,9 \\
\hline 17 & Fumo em folhas & 978 & 921 & 57 & 6,2 & 1,6 & 1,6 & 2,7 \\
\hline 18 & Couros e peles & 956 & 872 & 84 & 9,6 & 1,6 & 1,5 & 3,9 \\
\hline 19 & Suco de laranja & 869 & 813 & 56 & 6,9 & 1,4 & 1,4 & 2,6 \\
\hline \multirow[t]{3}{*}{20} & Alumínio em bruto & 813 & 676 & 137 & 20,3 & 1,3 & 1,2 & 6,4 \\
\hline & SUBTOTAL & 30.918 & 29.352 & 1.566 & 5,3 & 51,2 & 50,4 & 73,2 \\
\hline & TOTAL & 60.362 & 58.223 & 2.139 & 3,7 & 100,0 & 100,0 & 100,0 \\
\hline
\end{tabular}

Fonte: SISCOMEX

\section{Fonte: MDIC/SECX}

Atenta-se para o início dos anos 2000 onde a empresa brasileira, decidindo apostar no crescimento da aviação regional chinesa, instala um escritório comercial na China. Em seguida conclui a venda de cinco aviões ERJ 145 para a companhia aérea chinesa Sichuan Airlines (LAZARRINI, BOURGEOIS, 2010). Novos pedidos foram feitos pela empresa chinesa Southern Airlines, porém, a Embraer passa a enfrentar sua rival internacional, a canadense Bombardier que possuía interesse em vender aviões para a mesma companhia área, a qual inicia uma campanha para tentar impedir a finalização do contrato de venda da empresa brasileira com a China Southern Airlines. Entretanto, foi finalizada a venda de mais vinte aviões brasileiros ERJ 145, impondo a empresa canadense a procurar novos mercados. Com vendas cada mais expressivas na China, a Embraer começa a perceber que o intuito chinês não estava somente em importar aeronaves prontas, e sim utilizar da disputa entre a Bombardier e a Embraer para forçar uma das duas a fabricarem partes das aeronaves em 
território chinês. A legislação chinesa previa que os contratos das companhias aéreas, embora fossem autônomas, fossem submetidas à State Development and Planning Commission (SDPC), o qual regulava todos os contratos empresariais externos com o intuito do desenvolvimento de setores estratégicos da economia chinesa. Nesse sentido representantes da SDPC passaram a pressionar a empresa brasileira para que desse fomento a uma cooperação industrial com parceiros chineses, o interesse do Governo chinês estava em viabilizar a participação de setores industriais no desenvolvimento conjunto das aeronaves a serem comercializadas pela Embraer. Com a resistência da Embraer em sediar 0 pedido feito pelos chineses de criar uma empresa no âmbito tecnológico cooperacional, a China suspende todas as negociações com os brasileiros e, também, com os canadenses. Em seguida, decide elevar os impostos de importações e de comercialização no âmbito de aeronaves (BIATO, 2010).

Não tendo escolhas e com o perigo de perder o grande mercado de importações da China, a Embraer cede ao pedido chinês e assinou uma carta de intenções com a empresa estatal AVIC II, com o objetivo de compartilhar a tecnologia de manufatura e desenvolver, juntos com os chineses, novas aeronaves. Em 2002, um acordo foi assinado, evolvendo investimentos da unidade de montagem de aviões da Harbin, na Manchúria, feita para montar jatos ERJ 145. A criação da joint venture deu-se em seguida, com participações de $51 \%$ da Embraer e $49 \%$ da empresa chinesa Harbin, foi criado a empresa chamada Harbin Embraer Aircraft Industry Co.Ltd (LAZARRINI e BOURGEOIS, 2010). Logo em 2007, devido ao sucesso da cooperação brasileira e chinesa, a Embraer passa a enfrentar grandes novos concorrentes na criação de aviões na China, perdendo grande parte do seu mercado.

$\mathrm{Na}$ cooperação para a construção de aviões entre a Embraer e a estatal chinesa AVIC II, é visto o interesse maior da China em conseguir aprender a tecnologia brasileira de montagem, para a construção de seus próprios aviões. Neste quesito pode-se observar a mudança nos interesses dos agentes. Passa-se a ter uma relação com caracterização de Norte-Sul, onde o Brasil encontra-se pressionado e sem alternativas para se auto impor diante das exigências do 
governo Comunista Chinês. O que influencia no jogo político e principalmente no comércio.

O Brasil durante o governo Lula (2003-2011) mesmo não sendo o principal exportador para o mercado chinês, engajou de forma mais enfática na relação comercial com a China. Grandes propostas foram criadas e implantadas neste período com o país asiático. A criação da Agenda China (2008), foi um grande fator de desenvolvimento da Política de Desenvolvimento Produtivo (PDP) brasileira. Surgindo em um momento favorável para a interlocução do públicoprivado. A criação da Agenda teve como principal objetivo permitir aprofundar as transações econômicas comerciais com o país Asiático e primordialmente tentar ajustar os desequilíbrios da pauta exportadora brasileira, tendo o foco em aumentar a participação de produtos industrializados para a Pequim(AGENDA BRASIL CHINA, 2008) ${ }^{11}$.

Outro projeto do Governo Lula, foi a criação do Plano de Ação Conjunta entre o Governo da República Federativa do Brasil e o Governo da República Popular da China, 2010-2014. O principal objetivo estava em promover o desenvolvimento da Parceria Estratégica Brasil-China e definir os objetivos, metas concretas e orientações para cooperação bilateral entre 2010-2014. O plano de fato aprofundou as relações bilaterais em todas as áreas. Sendo aprimoradas as relações políticas e foi implementada em todas as áreas econômica-comercial dando ênfase no setor agrícola brasileiro e na área de Energia e Mineração. A COSBAN foi o principal órgão inspecionador de todo o Plano de Ação Conjunta, tendo reuniões anuais ${ }^{12}$.

De fato, as implementações colocadas no governo Lula com a China, demonstrarão, a partir de 2014, o crescimento da balança comercial entre os países, porém, não alterou a pauta exportadora e importadora brasileira para a China. Como exposto na tabela XIX e X, manteve-se a ordem contemporânea da interação, com as exportações de commodities brasileiras e as importações de

\footnotetext{
${ }^{11}$ AGENDA CHINA-BRASIL, 2008

12 PLANO DE AÇÃO BILATERAL BRASIL-CHINA, 2010-2014.
} 
produtos chineses de alto valor agregado. As exportações brasileiras para a China alcançaram a margem de US $\$ 16,4$ bilhões e a corrente comercial supriu o valor estimado de US $\$ 30$ bilhões para US $\$ 36,5$ bilhões, em 2010. O que tornará a China, em 2009, como o principal parceiro comercial do Brasil, dando margem para o crescimento gigantesco do comercio bilateral em 2014, em anexo XI e XII.

TABELA XI: PRINCIPAIS PARCEIROS COMERCIAIS DO BRASIL (2014 E 2015 )

\begin{tabular}{|c|c|c|c|c|c|}
\hline Descrição & $\begin{array}{c}2014 \\
\text { (Jan-Mar) }\end{array}$ & $\begin{array}{l}\text { Part. \% } \\
\text { no total }\end{array}$ & $\begin{array}{c}2015 \\
\text { (Jan-Mar) }\end{array}$ & $\begin{array}{l}\text { Part.\% } \\
\text { no total }\end{array}$ & $\begin{array}{c}\text { Var. } \% \\
2014-2015\end{array}$ \\
\hline $\begin{array}{l}\text { T o t a I G e r a l } \\
\text { Países selecionados }\end{array}$ & $\begin{array}{l}49,59 \\
28,21\end{array}$ & $\begin{array}{c}100,0 \% \\
56,9 \%\end{array}$ & $\begin{array}{l}42,78 \\
23,31\end{array}$ & $\begin{array}{c}100,0 \% \\
54,5 \%\end{array}$ & $\begin{array}{l}-13,7 \% \\
-17,4 \%\end{array}$ \\
\hline China & 9,58 & 19,3\% & 6,19 & $14,5 \%$ & $-35,4 \%$ \\
\hline Estados Unidos & 5,82 & $11,7 \%$ & 5,82 & $13,6 \%$ & $0,1 \%$ \\
\hline Argentina & 3,55 & $7,2 \%$ & 3,07 & $7,2 \%$ & $-13,6 \%$ \\
\hline Países Baixos & 2,92 & $5,9 \%$ & 2,25 & $5,3 \%$ & $-22,9 \%$ \\
\hline Alemanha & 1,23 & $2,5 \%$ & 1,34 & $3,1 \%$ & $8,6 \%$ \\
\hline Japão & 1,52 & $3,1 \%$ & 1,20 & $2,8 \%$ & $-20,7 \%$ \\
\hline Chile & 1,00 & $2,0 \%$ & 0,91 & $2,1 \%$ & $-9,3 \%$ \\
\hline Itália & 0,93 & $1,9 \%$ & 0,87 & $2,0 \%$ & $-6,4 \%$ \\
\hline Reino Unido & 0,92 & $1,9 \%$ & 0,85 & $2,0 \%$ & $-7,8 \%$ \\
\hline México & 0,74 & $1,5 \%$ & 0,80 & $1,9 \%$ & $8,6 \%$ \\
\hline
\end{tabular}

Fonte: MRE/ MDIC

TABELA XII: PRINCIPAIS PARCEIROS COMERCIAIS DA CHINA 2011

\begin{tabular}{|c|c|c|c|c|c|}
\hline & \multirow[b]{2}{*}{ Paises } & \multicolumn{4}{|c|}{2011} \\
\hline & & $\begin{array}{c}\text { Corrente de } \\
\text { Comércio } \\
\text { (US\$ Bilhões) } \\
\end{array}$ & $\begin{array}{l}\text { Exportações } \\
\text { (US\$ Bilhőes) }\end{array}$ & $\begin{array}{l}\text { Importações } \\
\text { (US\$ Bilhões) }\end{array}$ & $\begin{array}{c}\text { Saldo } \\
\text { (US\$ Bilhões) }\end{array}$ \\
\hline 10 & Estados Unidos & 446,65 & 324,49 & 122,15 & 202,34 \\
\hline 20 & Japão & 342,89 & 148,30 & 194,59 & $-46,29$ \\
\hline 3음 & Hong Kong & 283,52 & 268,03 & 15,50 & 252,53 \\
\hline 4은 & Coreia do Sul & 245,63 & 82,92 & 162,71 & $-79,79$ \\
\hline 50 & Alemanha & 169,15 & 76,43 & 92,72 & $-16,28$ \\
\hline 60 & Taiwan & 160,03 & 35,11 & 124,92 & $-89,81$ \\
\hline 70 & Austrália & 116,63 & 33,91 & 82,72 & $-48,81$ \\
\hline 80 & Malásia & 90,03 & 27,89 & 62,14 & $-34,25$ \\
\hline 9옹 & Federação Russa & 79,25 & 38,90 & 40,35 & $-1,44$ \\
\hline 100 & Brasil & 77,10 & 44,30 & 32,80 & 11,50 \\
\hline 110 & Índia & 73,92 & 50,54 & 23,37 & 27,17 \\
\hline
\end{tabular}


Fonte: Conselho Empresarial Brasil-China ${ }^{13}$

\section{TABELA XIX: BRASIL PRINCIPAIS PRODUTOS IMPORTADOS DA CHINA (2013-2014)}

\begin{tabular}{|c|c|c|c|c|c|c|c|}
\hline \multirow{2}{*}{$\begin{array}{l}\text { IMPORTAÇÕES } \\
\text { PRODUTOS OU FAMÍLIAS DE PRODUTOS }\end{array}$} & \multicolumn{2}{|c|}{2013} & \multicolumn{2}{|c|}{2014} & \multirow[b]{2}{*}{$\begin{array}{l}\text { Var. (\%) } \\
\text {-USS }\end{array}$} & \multirow[b]{2}{*}{$\begin{array}{c}\text { Var.(\%) } \\
\text { Qte (10 mil) }\end{array}$} & \multirow[b]{2}{*}{$\begin{array}{l}\text { Participação na } \\
\text { pauta em } \\
2014 \text { (USS) }\end{array}$} \\
\hline & $\begin{array}{c}\text { USS } \\
\text { (milhões) }\end{array}$ & $\begin{array}{c}\text { Qte } \\
(10 \mathrm{mil})\end{array}$ & $\begin{array}{c}\text { USS } \\
\text { (milhŏes) }\end{array}$ & $\begin{array}{c}\text { Qte } \\
(10 \mathrm{mil})\end{array}$ & & & \\
\hline Máquinas, aparelhos e materiais elétricos e suas partes & 10.869 & 49.612 & 10.897 & 49.640 & $0,3 \%$ & $0,1 \%$ & $29,2 \%$ \\
\hline Aparelhos elétricos para telefonia ou telegrafia & 2.519 & 10.570 & 3.029 & 11.237 & $20,2 \%$ & $6,3 \%$ & $8,1 \%$ \\
\hline Aparelhos e partes para rádio e televisão & 1.907 & 2.100 & 1.512 & 1.793 & $-20,7 \%$ & $-14,6 \%$ & $4,1 \%$ \\
\hline Circuitos integrados e microconjuntos eletrônicos & 1.024 & 93.225 & 982 & 100.674 & $-4,1 \%$ & $8,0 \%$ & $2,6 \%$ \\
\hline Transformadores elétricos, conversores elétricos estáticos & 537 & 195.263 & 548 & 225.252 & $1,9 \%$ & $15,4 \%$ & $1,5 \%$ \\
\hline Aquecedores elétricos de água & 449 & 6.479 & 492 & 6.235 & $9,7 \%$ & $-3,8 \%$ & $1,3 \%$ \\
\hline Máquinas e aparelhos mecânicos e suas partes & 8.132 & 876 & 7.151 & 869 & $\cdot 12,1 \%$ & $.0,8 \%$ & $19,2 \%$ \\
\hline Partes e acessórios para máquinas e equipamentos mecânicos & 1.547 & 6.782 & 1.317 & 4.696 & $-14,9 \%$ & $-30,8 \%$ & $3,5 \%$ \\
\hline Máquinas automáticas para processamento de dados & 835 & 6.822 & 673 & 5.551 & $-19,3 \%$ & $-18,6 \%$ & $1,8 \%$ \\
\hline Máquinas e aparelhos de ar condicionado & 477 & 53 & 542 & 54 & $13,8 \%$ & $1,1 \%$ & $1,5 \%$ \\
\hline Bombas e compressores de ar ou de vácuo & 466 & 4.119 & 495 & 3.762 & $6,2 \%$ & $-8,7 \%$ & $1,3 \%$ \\
\hline Máquinas e aparelhos para impressão & 550 & 122 & 492 & 96 & $-10,6 \%$ & $-21,2 \%$ & $1,3 \%$ \\
\hline Produtos químicos orgânicos & 2.184 & . & 2.230 & . & $2,1 \%$ & - & $6 \%$ \\
\hline Ferro fundido, ferro e aço & 978 & . & 1.388 & . & $41,9 \%$ & - & $3,7 \%$ \\
\hline
\end{tabular}

Fonte: Conselho Empresarial Brasil-China

\section{TABELA X: PAUTA DE EXPORTAÇÃO DO BRASIL PARA A CHINA (2013-2014)}

\begin{tabular}{|c|c|c|c|c|c|c|c|}
\hline \multirow{2}{*}{$\begin{array}{l}\text { EXPORTAÇŌES } \\
\text { PRODUTOS OU FAMÍLIAS DE PRODUTOS }\end{array}$} & \multicolumn{2}{|c|}{2013} & \multicolumn{2}{|c|}{2014} & \multirow[b]{2}{*}{$\begin{array}{l}\text { Var. (\%)- } \\
\text { UsS }\end{array}$} & \multirow[b]{2}{*}{$\begin{array}{l}\text { Var.(\%) } \\
\text { Ton (mil) }\end{array}$} & \multirow{2}{*}{$\begin{array}{l}\text { Participação na } \\
\text { pauta em } 2014 \\
\text { (US\$) }\end{array}$} \\
\hline & $\begin{array}{c}\text { USS } \\
\text { (milhổes) }\end{array}$ & Ton (mil) & $\begin{array}{c}\text { USS } \\
\text { (milhỗes) }\end{array}$ & Ton (mil) & & & \\
\hline Soja, mesmo triturada & 17.148 & 32.252 & 16.615 & 32.664 & $-3,1 \%$ & $1 \%$ & $40,9 \%$ \\
\hline Minérios de ferro e seus concentrados & 15.933 & 170.709 & 12.303 & 179.877 & $-22,8 \%$ & $5 \%$ & $30,3 \%$ \\
\hline Óleos brutos de petróleo & 4.035 & 5.976 & 3.473 & 5.576 & $-13,9 \%$ & $-7 \%$ & $8,6 \%$ \\
\hline Celulose & 1.347 & 2.681 & 1.424 & 3.061 & $5,7 \%$ & $14 \%$ & $3,5 \%$ \\
\hline Açúcares & 1.432 & 3.496 & 880 & 2.282 & $-38,6 \%$ & $-35 \%$ & $2,2 \%$ \\
\hline Couros e peles, não preparados & 429 & 187 & 554 & 188 & $29,1 \%$ & $1 \%$ & $1,4 \%$ \\
\hline Carne de aves & 441 & 190 & 519 & 228 & $17,7 \%$ & $20 \%$ & $1,3 \%$ \\
\hline Ferro-ligas & 497 & 57 & 504 & 42 & $1,4 \%$ & $-26 \%$ & $1,2 \%$ \\
\hline Óleo de soja & 517 & 529 & 340 & 396 & $-34,3 \%$ & $-25 \%$ & $0,8 \%$ \\
\hline Tabaco não manufaturado & 454 & 56 & 334 & 44 & $-26,5 \%$ & $-22 \%$ & $0,8 \%$ \\
\hline Algodão, não cardado nem penteado & 189 & 96,6 & 333 & 180,6 & $75,8 \%$ & $87 \%$ & $0,8 \%$ \\
\hline Pasta química de madeira, para dissolução & 230 & 273 & 282 & 310 & $22,8 \%$ & $14 \%$ & $0,7 \%$ \\
\hline
\end{tabular}

Fonte: Conselho Empresarial Brasil-China ${ }^{14}$

No governo Dilma Rousseff (2011-2016), percebe-se a continuação e as afirmações do incremente para o crescimento do comercio com a China, implantadas no governo anterior. Em 2011, o governo fez uma visita oficial à China, tendo como objetivos principais abrir novas oportunidades de negócios para as empresas brasileiras, ampliar e diversificar o comércio bilateral, incentivar

\footnotetext{
${ }^{13}$ Boletim de Investimentos Chineses no Brasil 2012-2013. Conselho Empresarial Brasil-China. Disponível em http://www.cebc.org.br/pt-br/projetos-e-pesquisas/investimentos-chineses-nobrasil/investimentos-chineses-no-brasil-2012-2013. Acesso em: 10 de abril de 2017.

14 Disponível em: http://www.cebc.org.br/pt-br/dados-e-estatisticas/comercio-bilateral/pauta-deexportacoes?y=2014> Acesso em : 13 de abril de 2017.
} 
a realização dos investimentos entre as partes de forma recíproca, promover e propiciar o maior engajamento na cooperação técnica internacional como foco na transferência de conhecimentos científicos e tecnológicos.

Devido ao engajamento dos países em linha de desenvolvimento em cooperarem e fortalecer o grupo político BRICS, aconteceu em 2015, em Brasília, uma reunião com todos os líderes dos participantes. Este evento foi aproveitado pelo governo brasileiro para tratar, de forma bilateral, a estender a abrangência do prazo do Plano de Ação Conjunta de 2010-2014, para 2015-2021. Neste encontro, foram tratados diversos assuntos abrangentes à economia brasileira e chinesa, firmando o novo Plano de Ação Conjunta, tendo como foco complementar o Plano Decenal de Cooperação 2012-2021 entre os Estados. Neste novo Plano, novas demandas foram acordadas, entre elas o compromisso de investimentos chineses no valor de US\$ 53 bilhões, a Construção da ferrovia transcontinental que ligará o Brasil ao Peru com o intuito de fornecer maior escoamento dos produtos brasileiros para a China, a adesão do Brasil ao Banco Asiático de Investimentos em Infraestrutura (BAll) e a construção de um sistema multilateral de comércio, com base no princípio de transparência, não discriminação, abertura e inclusão ${ }^{15}$. Não tendo nenhuma pauta de ampla relevância no âmbito de cooperação para desenvolvimento, o foco foi dado para o comércio entre os países.

Assim, os incrementos adicionados no governo Dilma deram maiores margens de investimentos chineses, consequentemente o aumento do intercâmbio comercial bilateral (anexo XIII). Contudo, as pautas exportadoras e importadoras não conseguiram ser dinamizadas, segundo dados do Conselho Empresarial Brasil-China, em anexo XIV e XV.

\section{TABELA XIII: EVOLUÇÃO DO COMÉRCIO BRASIL-CHINA 2006-2016}

\footnotetext{
15 Plano de Ação Conjunta Brasil China 2015-2021.
} 
Evolução do intercâmbio comercial Brasil - China

US\$ milhões

\begin{tabular}{|c|c|c|c|c|c|c|c|c|c|c|}
\hline \multirow[b]{2}{*}{ Anos } & \multicolumn{3}{|c|}{ Exportações } & \multicolumn{3}{|c|}{ Importações } & \multicolumn{3}{|c|}{ Intercâmbio Comercial } & \multirow[b]{2}{*}{ Saldo } \\
\hline & Valor & Var.\% & $\begin{array}{l}\text { Part. \% } \\
\text { no total } \\
\text { do Brasil }\end{array}$ & Valor & Var.\% & $\begin{array}{l}\text { Part. \% } \\
\text { no total } \\
\text { do Brasil }\end{array}$ & Valor & Var.\% & $\begin{array}{l}\text { Part. \% } \\
\text { no total } \\
\text { do Brasil }\end{array}$ & \\
\hline 2006 & 8.402 & $22,9 \%$ & $6,10 \%$ & 7.990 & $49,2 \%$ & $8,75 \%$ & 16.303 & $33,7 \%$ & $7,11 \%$ & 502 \\
\hline 2007 & 10.749 & $27,9 \%$ & $6,69 \%$ & 12.621 & $58,0 \%$ & $10,46 \%$ & 23.370 & $43,3 \%$ & $8,31 \%$ & -1.872 \\
\hline 2008 & 16.523 & $53,7 \%$ & $8,35 \%$ & 20.044 & $58,8 \%$ & $11,59 \%$ & 36.567 & $56,5 \%$ & $10,96 \%$ & -3.522 \\
\hline 2009 & 21.004 & $27,1 \%$ & $13,73 \%$ & 15.911 & $-20,6 \%$ & $12,46 \%$ & 36.915 & $1,0 \%$ & $13,15 \%$ & 5.093 \\
\hline 2010 & 30.786 & $46,6 \%$ & $15,25 \%$ & 25.595 & $60,9 \%$ & $14,08 \%$ & 56.381 & $52,7 \%$ & $14,69 \%$ & 5.190 \\
\hline 2011 & 44.315 & $43,9 \%$ & $17,31 \%$ & 32.791 & $28,1 \%$ & $14,49 \%$ & 77.105 & $36,8 \%$ & $15,99 \%$ & 11.524 \\
\hline 2012 & 41.228 & $-7,0 \%$ & $17,00 \%$ & 34.251 & $4,5 \%$ & $15,35 \%$ & 75.479 & $-2,1 \%$ & $16,21 \%$ & 6.976 \\
\hline 2013 & 46.026 & $11,6 \%$ & $19,02 \%$ & 37.304 & $8,9 \%$ & $15,56 \%$ & 83.330 & $10,4 \%$ & $17,30 \%$ & 8.722 \\
\hline 2014 & 40.616 & $-11,8 \%$ & $18,04 \%$ & 37.345 & $0,1 \%$ & $16,30 \%$ & 77.961 & $-6,4 \%$ & $17,16 \%$ & 3.271 \\
\hline 2015 & 35.608 & $-12,3 \%$ & $18,63 \%$ & 30.719 & $-17,7 \%$ & $17,92 \%$ & 66.327 & $-14,9 \%$ & $18,29 \%$ & 4.888 \\
\hline f jan-or & 30.710 & $-2,1 \%$ & $20,06 \%$ & 19.261 & $-29,2 \%$ & $16,81 \%$ & 49.971 & $-14,7 \%$ & $18,67 \%$ & 11.449 \\
\hline
\end{tabular}

Fonte: MRE/MDIC

TABELA XIV: PAUTA DE EXPORTAÇÃO DO BRASIL PARA A CHINA (2015-2016)

\begin{tabular}{|c|c|c|c|c|c|c|c|}
\hline \multirow[b]{2}{*}{ Exportações } & \multicolumn{2}{|c|}{2015} & \multicolumn{2}{|c|}{2016} & \multirow{2}{*}{$\begin{array}{c}\text { Var. (\%) } \\
\text { US\$ }\end{array}$} & \multirow{2}{*}{$\begin{array}{l}\text { Var. }(\%) \\
\text { Ton (mil) }\end{array}$} & \multirow{2}{*}{$\begin{array}{l}\text { Participação } \\
\text { na pauta em } \\
2016 \text { (US\$) }\end{array}$} \\
\hline & $\begin{array}{c}\text { US\$ } \\
\text { (milhões) }\end{array}$ & $\begin{array}{l}\text { Ton } \\
\text { (mil) }\end{array}$ & \begin{tabular}{c|} 
US\$ \\
(milhões)
\end{tabular} & $\begin{array}{l}\text { Ton } \\
\text { (mil) }\end{array}$ & & & \\
\hline Minérios de ferro e seus concentrados & 965 & 21.809 & 685 & 29.691 & $-29 \%$ & $36 \%$ & $21,3 \%$ \\
\hline Soja, mesmo triturada & 193 & 493 & 672 & 1.904 & $248 \%$ & $286 \%$ & $20,9 \%$ \\
\hline Óleos brutos de petróleo & 629 & 2.048 & 460 & 2.477 & $-27 \%$ & $21 \%$ & $14,3 \%$ \\
\hline Pastas químicas de madeira, exceto para dissolução & 255 & 577 & 318 & 680 & $25 \%$ & $18 \%$ & $9,9 \%$ \\
\hline Cobre afinado e ligas de cobre, em formas brutas & 71 & 12 & 109 & 24 & $54 \%$ & $98 \%$ & $3,4 \%$ \\
\hline Açúcares no estado sólido & 105 & 317 & 103 & 376 & $-2 \%$ & $18 \%$ & $3,2 \%$ \\
\hline Fornos elétricos industriais ou de laboratório & - & - & 94 & 0,7 & - & - & $2,9 \%$ \\
\hline Carne de aves & 81 & 39 & 91 & 53 & $12 \%$ & $33 \%$ & $2,8 \%$ \\
\hline Carne bovina, congeladas & - & - & 88 & 20 & - & - & $2,7 \%$ \\
\hline Couros e peles curtidos/em crosta, não preparados & 79 & 25 & 72 & 31 & $-9 \%$ & $26 \%$ & $2,2 \%$ \\
\hline Ferro-ligas & 102 & 10 & 54 & 11 & $-48 \%$ & $14 \%$ & $1,7 \%$ \\
\hline Veículos aéreos (e.g. helicópteros, aviões) & - & - & 46 & 0,037 & - & - & $1,4 \%$ \\
\hline Outros & 397 & 612 & 421 & 1.156 & $6 \%$ & $89 \%$ & $13,1 \%$ \\
\hline
\end{tabular}

Fonte: Conselho Empresarial Brasil-China

\section{TABELA XV: BRASIL PRINCIPAIS PRODUTOS IMPORTADOS DA CHINA (2015-2016)}




\begin{tabular}{|c|c|c|c|c|c|c|c|}
\hline \multirow[b]{2}{*}{ Importações } & \multicolumn{2}{|c|}{2015} & \multicolumn{2}{|c|}{2016} & \multirow[b]{2}{*}{$\begin{array}{c}\operatorname{Var} .(\%) \\
\text { US\$ }\end{array}$} & \multirow{2}{*}{$\begin{array}{c}\text { Var. }(\%) \\
\text { Qte (10 } \\
\text { mil) }\end{array}$} & \multirow{2}{*}{$\begin{array}{c}\text { Participação } \\
\text { na pauta em } \\
2016 \text { (US\$) }\end{array}$} \\
\hline & $\begin{array}{c}\text { US\$ } \\
\text { (milhões) }\end{array}$ & \begin{tabular}{|c|} 
Qte \\
$(10 \mathrm{mil})$
\end{tabular} & $\begin{array}{c}\text { US\$ } \\
\text { (milhões) }\end{array}$ & \begin{tabular}{|c|} 
Qte \\
$(10 \mathrm{mil})$
\end{tabular} & & & \\
\hline Máquinas, aparelhos e materiais elétricos e suas partes & 1.833 & 854.722 & 917 & 407.955 & $-50 \%$ & $-52 \%$ & $23 \%$ \\
\hline Aparelhos elétricos para telefonia ou telegrafia & 511 & 1.775 & 293 & 894 & $-43 \%$ & $-50 \%$ & $7,3 \%$ \\
\hline Aparelhos e partes para rádio e TV & 236 & 331 & 86 & 158 & $-64 \%$ & $-52 \%$ & $2,1 \%$ \\
\hline Circuitos integrados e microconjuntos eletrônicos & 146 & 18.678 & 67 & 10.957 & $-54 \%$ & $-41 \%$ & $1,7 \%$ \\
\hline Máquinas e aparelhos, elétricos, com função própria & 45 & 2.241 & 57 & 4.394 & $25 \%$ & $96 \%$ & $1,4 \%$ \\
\hline Transformadores elétricos, conversores elétricos estáticos & 86 & 41.779 & 41 & 13.494 & $-52 \%$ & $-68 \%$ & $1,0 \%$ \\
\hline Máquinas, aparelhos e instrumentos mecânicos e suas partes & 1.070 & 18.112 & 653 & 11.164 & $-39 \%$ & $-38 \%$ & $16 \%$ \\
\hline Partes e acessórios para aparelhos mecânicos & 181 & 656 & 107 & 316 & $-41 \%$ & $-52 \%$ & $2,7 \%$ \\
\hline Cábreas; guindastes, incluídos os de cabos; pontes & 21 & 0,01 & 60 & 0,03 & $181 \%$ & $280 \%$ & $1,5 \%$ \\
\hline Máquinas e aparelhos para impressão & 70 & 10 & 42 & 8 & $-40 \%$ & $-23 \%$ & $1,0 \%$ \\
\hline Máquinas automáticas para processamento de dados & 80 & 828 & 42 & 406 & $-48 \%$ & $-51 \%$ & $1,0 \%$ \\
\hline Bombas de ar ou de vácuo, compressores e ventiladores & 89 & 787 & 32 & 328 & $-64 \%$ & $-58 \%$ & $0,8 \%$ \\
\hline Embarcações e estruturas flutuantes & 451 & 1,1 & 555 & 0,3 & $23 \%$ & $-69 \%$ & $14 \%$ \\
\hline
\end{tabular}

Fonte: Conselho Empresarial Brasil-China

Dessa forma, percebe-se que no século XXI que houve uma transformação na pauta da relação entre os países, o comércio tornou-se mais relevante e passou a influenciar as medidas de cooperação. Passando a não ser observado de forma empírica, uma relação bilateral com perspectiva horizontal. Perante isso a verticalização é imposta no momento em que os interesses das partes começa a se transformar em interesses para o crescimento próprio, principalmente pelo crescimento econômico. A China, devido a sua grande inserção no comércio mundial e o incremento das relações comerciais, faz com que o Brasil necessite muito mais do comércio com o país Asiático, do que os chineses precisam do Brasil, ficando evidente a utilização do crescente comércio entre as partes por partes dos chineses como prática de pressão sobre o Brasil, influenciando em diversas outras perspectivas, como no âmbito cooperacional. Diante da ótica do sistema mundo, os dois países ainda continuam com grandes características de países semiperiféricos, contudo a capacidade da China em fazer parte do centro é um fator muito importante na contemporaneidade. 


\section{CONSIDERAÇÕES FINAIS}

Esta pesquisa se propôs a analisar as relações de cooperação econômica e política entre o Brasil e a China, para esclarecer se houve ou não uma verticalização nas relações bilaterais. A partir das hipóteses levantadas e com elementos empíricos trazidos, utilizou-se a Teoria do Sistema Mundo para tratar destes fatores. Através dessa investigação, foi detectado, com maior clareza, oscilações bilaterais ao longo do tempo em termos de delimitações entre centro e semiperiferia. Sendo possível identificar uma provável verticalização na cooperação entre as partes, tornando-se o comércio como a principal pauta e grande influenciador na relação bilateral, a partir do século XXI.

Percebe-se que no início das relações sino-brasileiras foi adotado maior ênfase na cooperação Sul-Sul, tendo em vista dois estados semiperiféricos quebrando as barreiras internacionais ao realizarem a transferência de tecnologia, sendo uma cooperação caracterizada entre semiperiferias. Assim, o incremento da participação das empresas estatais brasileiras com as estatais chinesas, na década de 1980, a fim de desenvolver tecnologias avançadas, demonstra a passagem enfática de uma cooperação para o desenvolvimento mútuo. A própria join-venture criada posteriormente, entre a Companhia Vale do Rio Doce e a siderúrgica chinesa Baosteel, em 2001, inovou e criou grandes meios na captação de energia para a população brasileira e chinesa.

Nota-se que o acordo espacial assinado, o Protocolo de Pesquisa e Produção Conjunta de satélites Sino-brasileira (CBERS), em 1986, foi criado com o intuito de fugir da dependência de imagens territoriais tiradas dos países do centro. Foi identificado que o projeto conquistou grandes frutos. Atualmente o Brasil é um dos maiores distribuidores de imagens orbitais do mundo, influenciando até mesmo outros países, como os Estados Unidos, a disponibilizar as imagens de forma gratuita. Além disso, o programa foi capaz de promover a inovação na indústria espacial, tanto no Brasil quanto na China. As imagens obtidas a partir de satélites são cedidas para ambos os Estados. O que foi considerado, na época da assinatura do acordo, em 1985, o maior projeto de alta tecnologia até então assinado entre dois países semiperiféricos. 
Esses dois fatores de cooperação expõem uma estrutura, de certo modo, igualitária no arcabouço do sistema mundo, numa relação entre dois países da semiperiferia, e, denotam a dinâmica de cooperação técnica para troca de informações tecnológicas e cientificas, sendo uma das características centrais da premissa Sul-Sul. Entretanto, nota-se que após maior concentração de capital por parte da China e a intensidade no âmbito comercial com o Brasil, há uma mudança na interação entre os países. A impressão é que se passa a concretizar a ideia da divisão de um núcleo dominante e uma periferia dependente, que segundo Wallerstein (2004), interagem e atuam no mesmo sistema mundo como um todo.

A década de 1980 foi marcada pela grande exportação concentrada em produtos de valor agregado por parte brasileira para a China, já a pauta de importação do paíse sul-americano da China foi preenchida apenas por petróleo e alguns outros insumos farmacêuticos. Ao contrário da década de 1990, em que o Brasil passou a ter a sua principal pauta exportadora constituída basicamente de farelo de soja e minérios, passando a importar da China produtos de alto valor agregado, como máquinas. Deste modo, o interesse chinês passa a se concretizar por commodities brasileiras, 0 que os fornece maiores fontes para a industrialização. Enquanto que o Brasil, desde a década de 1990, não consegue dinamizar a sua produção para exportação e carece de toda uma estrutura econômica. Portanto, a balança comercial entre os países alavanca de forma agressiva e logo, em 2009, a China já ultrapassa os Estados Unidos e torna-se o principal parceiro comercial do Brasil, enquanto que para a China o Brasil constava na $14^{\circ}$ posição no ranking dos seus principais parceiros comerciais. Percebe-se, no caso comercial sino-brasileiro, uma estrutura entre centro e periferia (Norte-Sul), aquela caracterizada em que a periferia torna-se um grande exportador de bens de baixa categoria tendo uma relação de alto valor com o centro. O que impacta grandiosamente nas relações de cooperação entre os Estados.

Assim, denotando por outro ponto de análise, os interesses econômico conseguem se sobrepor e influenciar os interesses de cooperação políticas, como 
no caso do reconhecimento brasileiro da China como economia de mercado e o não apoio chinês, como retribuição, a cadeira do conselho de segurança das Nações Unidas.

Nota-se, também, outra consequência da influência econômica, no âmbito de cooperação técnica. O caso da criação da joint venture Harbin Embraer Aircraft Industry Co.Ltd, é um exemplo. A China utilizou de seus aparatos legais e de seu poder econômico para pressionar a empresa brasileira em montar seus aviões em território chinês, com o intuito de adquirir conhecimento da tecnologia brasileira de montagem de aviões. Além disso, nas reuniões entre as partes, acontecidas no século XXI, percebe-se que o intercâmbio comercial foi a principal pauta das discussões, deixando a cooperação para o desenvolvimento em segundo plano.

Assim, diante da ótica da atual conjuntura do sistema mundo moderno, onde as partes interagem entre si como um todo, a China e o Brasil continuam como Estados com características de semiperiferias. Entretanto, percebe-se que o locus do Brasil é aquele entre o Centro e a Periferia, já que consegue explorar os recursos e fontes dos países mais pobres, enquanto que a China, com seu grande desenvolvimento econômico, possui maiores capacidades em fazer parte do Centro, acabando por explorar Estados semiperiféricos e sua produção de bens primários ou industrializados com baixo valor agregado, como o Brasil.

Portanto, as relações entre o Brasil e a China são marcadas por oscilações e uma possível verticalização nas negociações de cooperação, no século XXI. Porém, no sentido mais amplo percebe-se que no século $X X$ alguns fatores da relação sino-brasileira que nos remete a uma relação entre países em desenvolvimento (Sul-Sul). Mas a partir do fortalecimento comercial, ocasionando a mudança das atitudes dos atores, podemos perceber que existe uma possível concretização de uma relação entre centro e semiperifeira (Norte-Sul), no século $X X I$. Ademais, é importante intensificar a análise desses fatores de pesquisa, de maneira mais específica, o que será proposto na continuidade do tema em pesquisas posteriores. 


\section{REFERÊNCIAS BIBLIOGRÁFICAS}

ARRUDA, José Jobson. Immanuel Wallerstein e o sistema mundial. Departamento de História - FFLCH/USP, São Paulo, p 167-174, 1983.

BIATO JUNIOR, Oswaldo. A Parceria estratégica Sino-Brasileira: Origens, Evolução e Perspectivas (1993-2006); Brasília: Fundação Alexandre Gusmão, 2010.

BECARD, Danielly. O que esperar das relações Brasil-China. Revista Social Política, v 19, n. Suplementar, p 31-44, 2011.

BECARD, Danielly S. Ramos. O Brasil e a República Popular da China: Política externa comparada e relações bilaterais (1974-2004). Brasília: editora FUNAG, 2008.

CAMERON, Rondo. Reviewed Work: The Modern World-System II: Mercantilism and the Consolidation of the European World-Economy, 1600-1750 by Immanuel Wallerstein. Massachusetts : The MIT Press, 1981.

CERVO, Luiz Amado. Socializando o desenvolvimento; uma história da cooperação técnica internacional do Brasil. Revista Brasileira de Política Internacional. pp.37-63, 1994.

DE NEGRI, Fernanda. Concorrência chinesa no mercado brasileiro: possíveis impactos da concessão, para a China, do status de economia de mercado. 2005.

GOUVEA, Raul. MONTOYA, Manuel. Brazil and China: Partners or Competitor? Designing Strategic Alliances in the Age of Uncertainty. University of New Mexico: AJLAS, Vol 26, 2013

GILPIN, Robert. The Challenge of Global Capitalism. Princeton University Press and copyrighted: Nova Jérsei, 2000.

. A economia política das relações internacionais. Princeton University Press: Nova Jérsei, 1987.

HAIBIN, Niu. Emerging Global partnership: Brazil and China. RBPI Vol 53, 2010

HOPKINS, Tercence K. World systems analysis There and methodology. SAGE Publications, Inc. April, 1982.

HOLANDA, Francisco Mauro. 40 anos das relações Brasil-China: de onde viemos, onde estamos, para onde vamos. In: LIMA, Sérgio Eduardo Moreira (organizador). Brasil-China 40 anos de relações diplomáticas. Brasília: FUNAG, pg 57-103, 2016. 
JENKINS, Rhys. China and Brazil: Economic Impacts of a Growing Relationship. Journal of Current Chinese Affair, v 41, p 21-47, 2012.

JONES, E.L. The Modern World-System II: Mercantilism and the Consolidation of the European World-Economy, 1600-1750. The economic history review, New York: Academic Press, 1980.

LAZARRINI, Sergio. BOURGEOIS, L.J. A Embraer na China: competindo em um ambiente regulado. Insper Instintuto de ensino e Pesquisa, 2010.

LORIMER, Doug. Imperialism the highest stage of capitalism. Resistence Books: Australia, 1999.

LEITE, Patrícia Soares. Brasil e a Cooperação Sul-Sul em três momentos de Política Externa. Brasília: editora FUNAG, 2011.

LIMA, Sergio E. Moreira (organizador). Brasil e China: 40 anos de relações diplomáticas: análises e documentos. Brasília: editora FUNAG, 2016.

MARX, Karl "The Eighteenth Brumaire of Louis Bonaparte" in The Marx-Engels Reader, ed. Robert C. Tucker (New York: Norton, 1972), 436.

MILANE, Carlos. CARVALHO, Tassia. Cooperação Sul-Sul e Política Externa: Brasil e China no Continente africano. El estudos internacionais v 1, jan-jun 2013, pp 11-35.

MARTINUSSEN, John Degnbol. PEDERSEN, Poul Engberg. Understanding International Development Cooperation. Londres: editora Zed Books, 2003.

MELUCCI, Marco. OLIVEIRA, Edson. Comércio Bilateral entre Brasil e China 1990. Universidade Vale do Paraíba, p 770-776.

OLIVEIRA, Henrique Altemani. Brasil-China; Uma nova aliança não inscrita?. Rev. Bras. Polít. Int. 53, p 88-106, 2010.

OLIVEIRA, Henrique Altemani. Brasil-China: trinta anos de uma parceria estratégica. Pontifícia Universidade Católica de São Paulo; 2004.

OLIVEIRA, Henrique Altemani. Brasil e China Cooperação Sul Sul e parceria estratégica. Rio de Janeiro: Fino Traço, 2012.

OLIVEIRA, Carlos Tavares; "China o Retorno á liderança mundial"; São Paulo: Editora Aduaneiras, 2012.

PRECIADO, Jaime. América Latina no Sistema-Mundo: questionamentos e alianças centro-periferia. CADERNO CRH, Salvador, v. 21, n. 53. Salvador, 2008 p. 253-268. 
ROSITO, Tatiana. Evolução das relações econômicas Brasil-China e perspectivas futuras. In: LIMA, Sérgio Eduardo Moreira (organizador). Brasil-China 40 anos de relações diplomáticas. Brasília: FUNAG, pg 57-103, 2016.

VIOTTI, Paul, KAUPPI, Mark. International Relations Theory. Pearson Education, 1999.

VADELL, Javier A. "The North of the South: the geopolitical implications of 'Pacific Consensus' in South America and the Brazilian Dilemma". In Latin American Policy, vol. 4, n. 1, p. 36-56, 2013.

WALLERSTEIN, Immanuel. World-Systems Analysis. London: Duck University Press, 2004.

. The modem world-system. III: the second era of great expansion of the capitalist world economy, 1730-1840. Academic Press, San Diego, 1989. p 372

The modern World-System IV: Centrist Liberalism Triumphant, 17891914. University of California Press: Berkeley, 2011.

As relações Bilaterais Brasil-China a Ascensão da China no sistema mundial e os desafios para o Brasil. IPEA: 2011. Dispnível em: <http://repositorio.ipea.gov.br/bitstream/11058/6889/1/Comunicados_n85_Rela\%C 3\%A7\%C3\%B5es_bilaterais.pdf>. Acesso em: 06 de março.

Agenda China. Disponível em: <http://www.cebc.org.br/sites/default/files/agendachina.pdf> Acesso em : 29/04/2017

CBERS: Satélite Sino-Brasileiro de Recursos Terrestres. CBERS: 2014. Disponível em: <http://www.cbers.inpe.br/hotsite/arquivos/Folder CBERS.pdf>. Acesso em: 06/06/2017.

Plano de Ação Conjunta entre o Governo da República Federativa do Brasil e o Governo da República Popular da China, 2010-2014. Disponívelem:<http://daimre.serpro.gov.br/atosinternacionais/bilaterais/2010/plano -de-acao-conjunta-entre-o-governo-da-republica-federativa-do-brasil-e-o-governoda-republica-popular-da-china-2010-2014> Acesso em 22/04/2017 
